UNITED NATIONS CONFERENCE ON TRADE AND DEVELOPMENT

MULTILATERAL INDEXED LOANS AND DEBT SUSTAINABILITY 



\title{
MULTILATERAL INDEXED LOANS AND DEBT SUSTAINABILITY
}

\author{
Alessandro Missale and Emanuele Bacchiocchi
}

No. 209

November 2012

Acknowledgements: The authors would like to thank Ugo Panizza who provided valuable comments and suggestions. 
The opinions expressed in this paper are those of the authors and are not to be taken as the official views of the UNCTAD Secretariat or its Member States. The designations and terminology employed are also those of the authors.

UNCTAD Discussion Papers are read anonymously by at least one referee, whose comments are taken into account before publication.

Comments on this paper are invited and may be addressed to the author, c/o the Publications Assistant, Macroeconomic and Development Policies Branch (MDPB), Division on Globalization and Development Strategies (DGDS), United Nations Conference on Trade and Development (UNCTAD), Palais des Nations, CH-1211 Geneva 10, Switzerland (fax no: +41 (0)22 917 0274). Copies of Discussion Papers may also be obtained from this address.

New Discussion Papers are available on the UNCTAD website at http://www.unctad.org. 


\section{Contents}

Abstract …

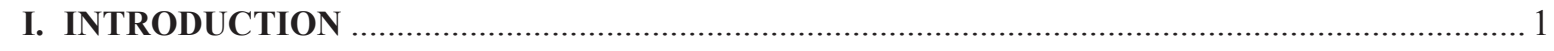

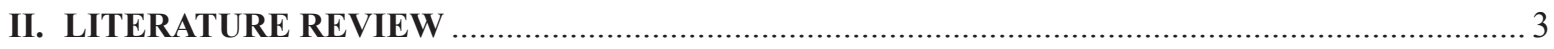

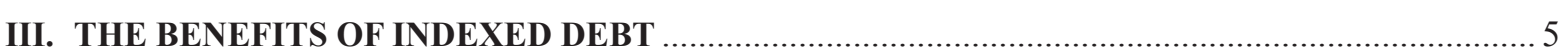

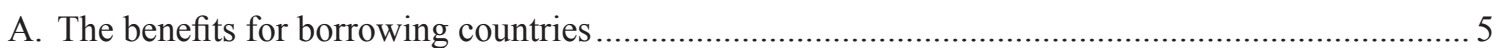

B. The benefits of indexed debt for multilateral lenders ...................................................................... 5

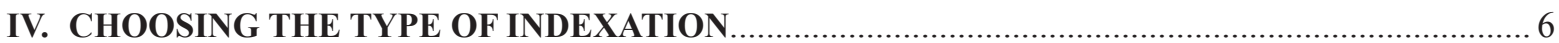
A. Indexing method

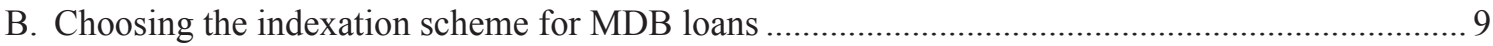

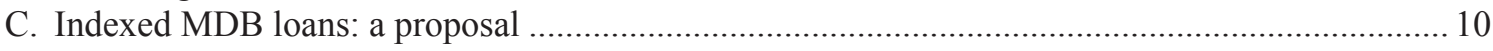

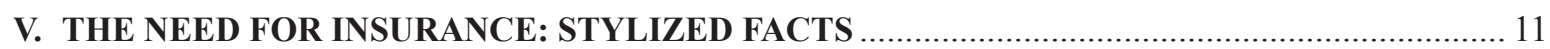

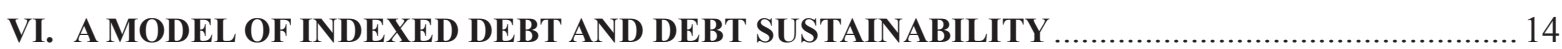

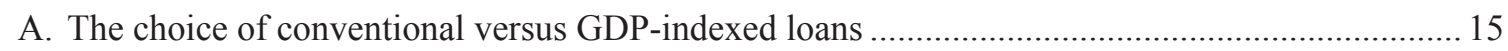

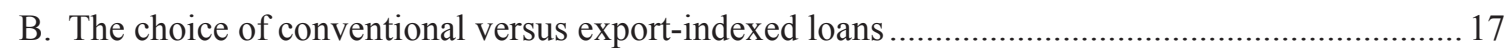

C. The choice of conventional versus domestic currency loans......................................................... 19

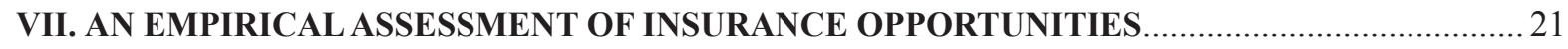

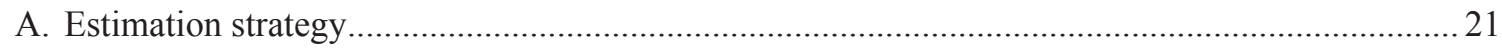

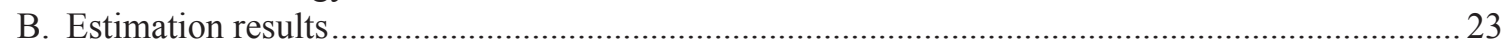

VIII. AN EMPIRICAL ASSESSMENT OF THE COST OF PROVIDING INSURANCE …....................28

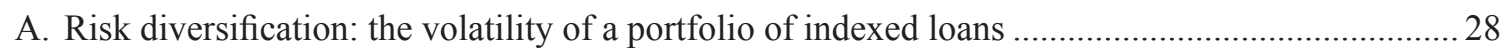

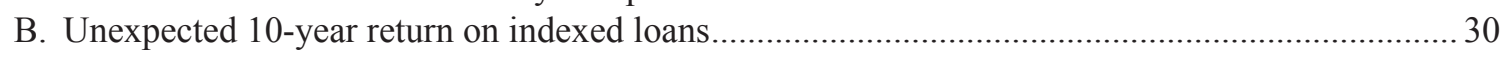

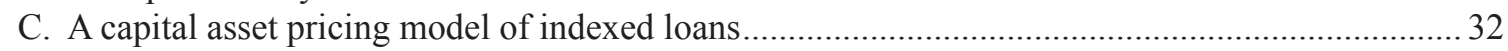

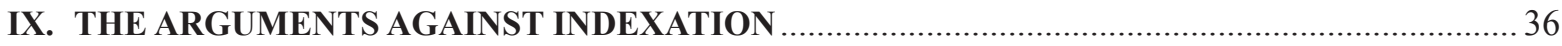

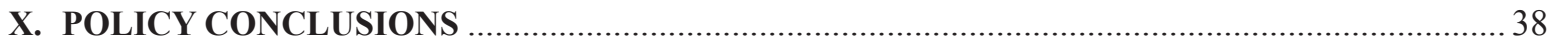

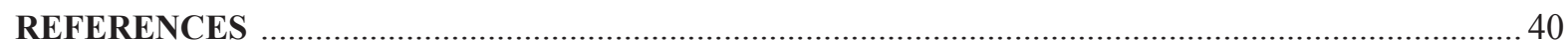

\section{List of tables}

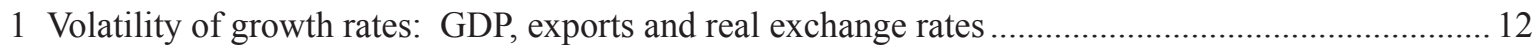

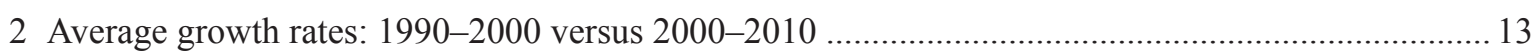

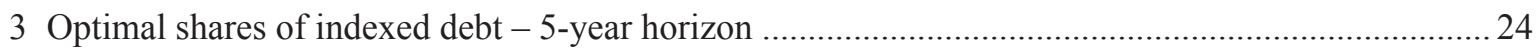

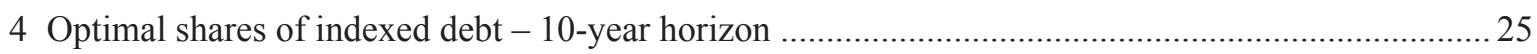

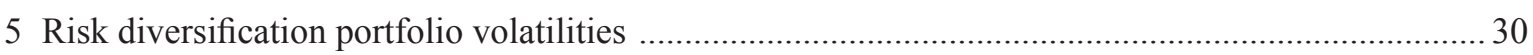

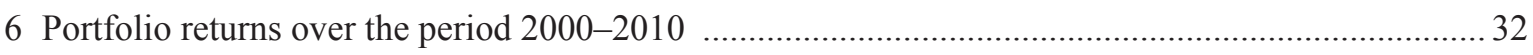

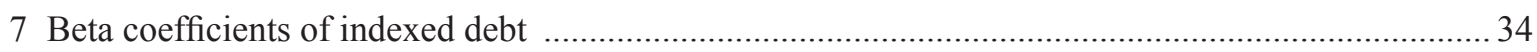

\section{List of figures}

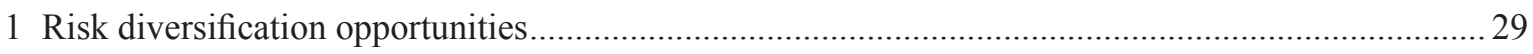

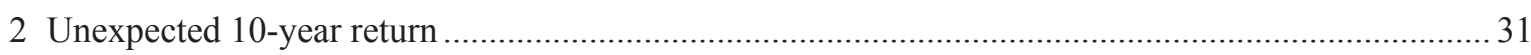





\title{
MULTILATERAL INDEXED LOANS AND DEBT SUSTAINABILITY
}

\author{
Alessandro Missale and Emanuele Bacchiocchi*
}

\begin{abstract}
We study the potential for introducing indexation on loans provided by multilateral lenders to low income countries (LICS), and thus whether a reform of their lending policy is feasible and economically justified. To this end, we provide new evidence for a group of 40 international development association (IDA) countries over the 1990-2010 period for three types of debt: (i) foreign currency loans indexed to real gross domestic product (GDP); (ii) foreign currency loans indexed to the dollar value of exports; and (iii) inflation-indexed loans denominated in local currency. We find that both GDP indexation and domestic currency lending are feasible policies, since individual country risk could be easily diversified in a portfolio of loans to IDA countries. The estimation of capital asset pricing model (CAPM) beta coefficients suggests that, while the risk of export-indexed loans is difficult to hedge, loans indexed to GDP or denominated in local currencies could be introduced at current interest rates; their risk premium is no greater than one per cent. The insurance that indexed debt might offer to LICs against macroeconomic shocks threatening their debt sustainability depends on the conditional covariances of GDP growth, real exchange-rate depreciation and net exports that we estimate as the covariances of the forecast errors obtained from a VAR model. The analysis shows that GDP-indexed or export-indexed loans would help to stabilize the debt ratio of the majority of IDA countries in our sample, but a larger number of them would benefit from a re-denomination of loans in local currency. A main lesson from our analysis is that a 'one size fits all solution' does not exist to the problem of stabilizing the debt ratio. This suggests that a reform of multilateral lending that is desirable to all LICs would be difficult to implement.
\end{abstract}

\section{INTRODUCTION}

It is commonly held that, by introducing greater state contingency in sovereign debt contracts, GDPindexed bonds may help stabilize the debt-to-GDP ratio, reduce the likelihood of debt crises and sovereign defaults and limit the pro-cyclicality of fiscal policy (see e.g. Borensztein and Mauro, 2004; Griffith-Jones and Sharma, 2006). The idea is that indexed debt can provide valuable insurance since its payments are linked to the underlying conditions of the borrower, notably those that impact on its capacity to pay. While debt instruments can either be indexed to GDP, exports or commodity prices, their key feature is that cash flows - coupons, principal or both - are linked to the borrower's ability to pay; they imply lower payments in times of output contractions, export shortfalls or terms of trade shocks, that is, precisely when a country struggles to honour its debt.

\footnotetext{
* The authors are associated with the United Nations Conference on Trade and Development and the Università degli Studi di Milano, respectively; e-mail: alessandro.missale@unctad.org and emanuele.bacchiocchi@unimi.it.
} 
In this paper, we evaluate the potential for introducing indexation on loans provided by multilateral development banks (MDBs) to low income countries and thus whether a reform of their lending policy is feasible and economically justified. In particular we investigate whether multilateral loans either indexed to GDP, or exports or denominated in domestic currency can reduce the LICs' vulnerability to adverse shocks to GDP, the exchange rate and net exports that threaten their debt sustainability. To this end, we provide new evidence for a group of 40 IDA countries over the 1990-2010 period for three types of debt: (i) foreign currency loans indexed to real GDP; (ii) foreign currency loans indexed to the dollar value of exports; and (iii) inflation-indexed loans denominated in local currency.

We extend the literature in several directions. We compare the benefits of GDP-indexed loans to other types of indexation: export-indexed loans and inflation-indexed loans denominated in domestic currency. In doing so, we pay particular attention to the currency denomination of debt obligations, an issue that has so far been neglected, studying to what extent GDP or export indexation can also reduce debt vulnerabilities arising from the exposure to real exchange-rate risk.

To assess the feasibility for multilateral lenders of a programme of indexed lending, we examine the potential for risk diversification, studying the risk-return characteristics of a portfolio of indexed loans to a group of 40 IDA countries. Portfolio risk analysis shows that individual country risk could be easily diversified, since the volatility of the MDB portfolio is much lower than the average volatility of individual loans for all types of indexation considered. The estimation of beta coefficients for individual country loans from a CAPM, where the Organisation for Economic Cooperation and Development (OECD) growth is taken as the relevant market-portfolio return, suggests that the risk of export-indexed loans is difficult to hedge because IDA countries' exports are strongly correlated with OECD growth and thus with the fiscal resources of multilateral lenders. By contrast, loans indexed to GDP or denominated in local currencies could be introduced at current interest rates because their risk premium is no greater than one per cent, while multilateral lenders would gain from a lower risk of debt distress.

More importantly, we investigate the role of indexed loans in reducing IDA countries' vulnerability to adverse shocks to output, exports and the real exchange rate, in a model where indexed debt helps to stabilize the debt ratio and thus reduce the likelihood of a debt crisis. The optimal type of indexation depends on the conditional variances and covariances of GDP growth, real exchange-rate depreciation and net exports that we estimate as the covariances of the forecast errors obtained from a VAR model of each IDA country over the period between 1990 and 2010.

We find strong evidence in favour of domestic currency loans indexed to inflation and some support to GDP indexation. Lending in the borrower's currency helps to stabilize the debt ratio against unanticipated movements in the real exchange rate that is the main cause of debt vulnerability. We also find supportive evidence for GDP-indexed loans, but while such instruments provide valuable insurance to a majority of IDA borrowers in our sample, they benefit a fewer number of countries than domestic currency loans. A main lesson from our analysis is that a 'one size fits all solution' does not exist to the problem of stabilizing the debt ratio.

A more serious obstacle for the introduction of GDP-indexed loans is that the MDB and the borrowing country must agree upon a country-specific baseline trend of GDP, since amortization payments must be indexed to deviations of realized GDP from its baseline trend for such loans to be attractive to countries with a high growth potential. On the other hand, lending in local currency is problematic because the real exchange rate of LICs tends to appreciate in the long run and at different rates in different countries. For LICs to be willing to borrow in local currency instead of conventional foreign currency loans, either the amount of transferred resources or their concessionality would have to be adjusted to individual countries' expected real appreciations. In the case of GDP indexation, the borrower would want to claim that its growth prospects are strong in order to set the highest possible baseline trend for GDP and thus reduce future debt payments. Were loans denominated in local currency, the borrower would overstate expected real appreciation to ask for a greater concessionality on its debt. On the other hand, the MDB would want 
to ensure itself an expected level of reflows comparable to those on conventional loans. As a result, both in the case of GDP indexation and domestic currency lending, a conflict of interests is likely to arise in the design of a contingent loan contract and an agreement may be difficult to reach.

After this introduction, in section II we review the literature on GDP-indexed debt and discuss the benefits of indexation in section III. Then, in section IV, we examine alternative indexing methods and their implications to identify an optimal scheme for MDBs' loans. In section V, we present preliminary evidence on the main risks affecting IDA countries. In section VI, we develop a simple model where the choice of debt instruments helps to stabilize the debt-to-GDP ratio and reduce the probability that the debt becomes unsustainable. This allows us to derive the optimal shares of GDP-indexed debt, exportindexed debt and domestic currency debt as a function of the stochastic relations between GDP growth, net exports and real exchange-rate depreciation. In section VII, these relations are estimated for a group of 40 IDA countries as the covariances of the forecast errors of VAR models for each country. In section VIII, we examine the cost for the MDBs of providing contingent loans to LICs by empirically investigating the extent of risk diversification accomplished by a portfolio of loans to a group of IDA countries. In section IX, we discuss the arguments against indexation. Section X concludes with policy implications.

\section{LITERATURE REVIEW}

Contingent debt contracts fall into two main categories. The first type of indexed debt has payments linked to an exogenous variable, that is, one out of the debtor country's control. Relevant examples of exogenous variables are the price of a country's export commodity or the growth rate of industrialized countries. A strong case for commodity-indexed debt was first made by Besley and Powell (1989) who called for intervention by multinational institutions in developing a market for such debt. ${ }^{1}$

The second type of indexed debt has payments linked to an endogenous variable which is at least partly under the control of the debtor country. A first proposal in this direction can be dated back to the work of Bailey (1983) who argued for converting the external debt into proportional claims on exports. Other possible endogenous indices are the country's total output or its trade balance. Lessard (1987) and Helpman (1989) contended that some sort of output indexation might be beneficial as a risk-sharing or hedging mechanism: risk-averse countries could shift some of their exposure to better diversified lenders.

Krugman (1988), Froot et al. (1989) and Kletzer et al. (1992) considered the relative merits of indexing debt to exogenous versus endogenous variables. This literature took for granted the insurance benefits of indexing the debt to variables proxying for the country's ability to pay; it did not investigate whether a greater insurance could be provided by indexing to commodity prices or GDP or exports and focused instead on the incentive effects and moral hazard costs of indexation. For instance, Krugman (1988) argued in favour of commodity-price indexation to minimize the risk of moral hazard implied by the debtor's ability to affect exports.

Although commodity-indexed debt may be as good an instrument for insurance and risk sharing as GDP- or export-indexed debt, in this paper we focus on the latter types of indexation for two reasons. First, while a few experiments have been made with commodity-price indexation, much less is known regarding GDP indexation despite the Argentine experiment and a growing literature on the benefits (and pricing) of GDP-indexed bonds. ${ }^{2}$ Second, we are interested in studying the potential for introducing indexation on loans provided by Multilateral Development Banks to low income countries and thus in a

\footnotetext{
1 More recently, recommendations for emerging countries to issue commodity-indexed debt have been made by Haldane (1999), Daniel (2001), Caballero (2003a, 2003b) and Atta-Mensah (2004).

2 See Griffith-Jones and Sharma (2006) and Costa et al. (2008) for a review of the Argentine and other experiences with GDP indexation.
} 
reform of lending policy that could find the largest possible application and not be confined to specific export producers as is the case with commodity-price indexation.

Interest in GDP indexation has been recently revived by the work of Shiller (1993, 2003, 2004, 2005) and Borensztein and Mauro (2004). With the aim to improve international risk sharing, Shiller proposes to create 'macro markets' for GDP-linked securities, taking the form of perpetual claims on a fraction of a country's GDP. Borensztein and Mauro propose the introduction of bonds with coupon payments augmented by the issuing country's GDP growth rate to reduce cyclical vulnerability and the probability of debt crises. In their view, GDP-indexed bonds should provide insurance against output contractions and act as an automatic stabilizer mechanism, allowing for greater flexibility in fiscal policy. ${ }^{3}$ Indexed bonds should limit the pro-cyclicality of fiscal policies, stabilize the debt-to-GDP ratio and thus reduce the likelihood of costly debt crises and sovereign defaults.

The literature on debt management has also emphasized the potential benefits of GDP-indexed bonds in supporting optimal taxation. By providing a hedge against shocks affecting the income tax base, GDPindexed bonds would minimize tax-rate adjustments and their costs (see e.g. Barro, 1995 and Missale, 1997).

The case for GDP indexation has been further put forth by Griffith-Jones and Sharma (2006) and Kamstra and Shiller (2010), while issuers' and investors' concerns have been addressed in two studies by the UN $(2005,2006)$ with the aim to solve the problems for their introduction and define a strategy for implementation. In fact, the introduction of GDP-indexed bonds runs into various difficulties. A first problem is the delay with which estimates of GDP become available and then later, sometimes substantial, revisions. A second problem is the complexity of the instrument that makes its pricing a difficult task. As a result, the empirical literature on pricing GDP-indexed bonds has grown fast (see e.g. Kruse et al., 2005; Pernice and Fagundez, 2005; Chamon and Mauro, 2006; Costa et al., 2008 and Ruban et al., 2008).

Pricing difficulties are instead not an obstacle for indexing non-marketable loans as those provided by MDBs to LICs. This makes the introduction of indexed loans by MDBs a more realistic project whose chances of success are worth investigating. A few papers exist, closely related to our analysis, that examine the potential for a reform of multilateral lending. Guillaumont (2003) and Cohen and Reisen (2007) contend that MDBs should provide loans to LICs with amortization payments indexed to the value of their exports. Tabova (2005) proposes to make such payments conditional on the growth rate of GDP. In particular, she examines the effectiveness of a scheme that partially exempts countries from debt service when growth is lower than expected using historical simulations of debt service to IDA. Drèze (2000b) suggests the use of GDP-indexed bonds (with a deductible) as part of a strategy to restructure the debt of the poorest countries. From a different perspective, Hausmann and Rigobon (2003) and Levy Yeyati (2007) argue that MDBs should provide inflation-indexed loans denominated in local currencies to reduce the exposure of low income countries to real exchange-rate movements which are a main cause of debt vulnerability.

\footnotetext{
${ }^{3}$ See Obstfeld and Peri (1998) and Drèze (2000a) for a discussion of the stabilization role of GDP-indexed bonds in advanced economies.
} 


\section{THE BENEFITS OF INDEXED DEBT}

Although contingent debt, and in particular GDP-indexed debt, would be a powerful instrument for international portfolio diversification and risk sharing, ${ }^{4}$ here we focus on the insurance benefits for low income countries and multilateral lenders.

\section{A. The benefits for borrowing countries}

Contingent debt contracts provide insurance benefits to debtor countries and their citizens against shocks affecting their income, net exports and tax revenues. In particular, GDP-indexed debt stabilizes the debt-to-GDP ratio against output contractions and slow growth while export-indexed debt limits the accumulation of external debt due to terms-of-trade shocks. Hence, indexed debt makes a country's debt position resilient to adverse shocks and enhances its sustainability. By linking debt payments to the borrower's ability to pay, debt either indexed to GDP or exports reduces the likelihood of debt crises and default. Furthermore, to the extent that indexation provides automatic relief to countries in distress, it disposes of explicit debt relief and of its related renegotiation and administrative costs.

Secondly, indexed debt makes fiscal policy less procyclical by acting as an 'automatic-stabilizer' mechanism. It does so by reducing the need for fiscal adjustment in bad times, when output or exports are lower than expected, and by forcing fiscal moderation in good times when GDP or exports are unexpectedly high. The 'fiscal space' created by a lower debt service during economic downturns can be particularly valuable because of the difficulties faced by debtor countries to access private capital markets. Moreover, indexed debt can benefit the poor in that it reduces pressure to cut spending for social programmes in bad times. As a built-in mechanism for macroeconomic stability, indexed debt is also beneficial for growth. ${ }^{5}$

\section{B. The benefits of indexed debt for multilateral lenders}

By reducing the likelihood that debtor countries run into repayment difficulties and eventually file for debt relief, indexed debt would not only be in the interest of the borrowers but also in that of multilateral lenders. They would both benefit from a lower risk of debt distress and a lower frequency of debt crises. Of course, it can be argued that explicit debt relief provides a simpler alternative than contingent debt to cope with adverse economic circumstances that impair the debtors' ability to pay. However, providing explicit insurance against macroeconomic shocks can be a more effective policy to deal with repayment difficulties because it avoids delays in delivering assistance, and saves on the costs of debt renegotiation and conditionality associated with explicit debt relief. Furthermore, to the extent that explicit relief is a sign of the lender's failure to evaluate the creditworthiness of the borrower or the profitability of the projects, reputational costs can be quite high.

Second, and importantly, to the extent that debt payments are contingent on economic performance, multilateral lenders need not decide in advance which countries are worth receiving large loans and which countries should instead obtain small grants, as it currently happens for IDA assistance under the debt sustainability framework (DSF). As poor growth or export performance would reduce payments on indexed loans and make them similar to grants, indexed loans could also be extended to countries where debt sustainability is considered at risk. As a matter of fact, debt sustainability is a forward looking concept; it depends on future economic growth which is hard to predict. Evaluating debt sustainability

\footnotetext{
${ }^{4}$ GDP-indexed bonds would allow investors to take an equity-like position in a foreign country's GDP.

${ }^{5}$ A further advantage of GDP indexation is that it supports optimal taxation. By providing a hedge against shocks to the tax base, GDP-indexed debt allows to minimize variations in tax rates and thus the welfare losses from tax distortions.
} 
requires forecasts of GDP, exports or the exchange rate twenty or thirty years from now which is an almost impossible task.

However, for a programme of indexed lending to be viable at the same expected costs of conventional lending, it must work as an insurance scheme. This requires that lower payments from countries experiencing low growth be offset by higher payments from fast growing countries. In other words, for MDBs to extend indexed loans to a larger number of countries at the same expected cost, opportunities for risk diversification must exist; GDP or export risk should not be correlated across countries for a diversified portfolio of loans to limit the MDBs' exposure to systematic risk. Finally, GDP-indexed or export-indexed debt enables investors to take an equity-like position in the borrower country. As GDP and export growth are main goals (together with poverty reduction) of multilateral lenders, it seems natural that MDBs would take a position on LICs' future growth prospects.

While in theory the potential benefits of contingent debt are undisputed, their practical relevance remains an open question. In fact, empirical research on GDP indexation has mainly focused on the investor side of the problem, for instance, by examining the extent of risk diversification provided by portfolios of GDPindexed bonds from different issuers or by evaluating how such bonds would be priced by the market. By contrast, little attention has been paid to measuring the benefits of indexation for borrowers. Indeed, empirical research has been confined to case studies and has mainly relied on a counterfactual analysis of the path of the debt-to-GDP ratio in case of GDP indexation. Furthermore, scant attention has been paid to the currency denomination of external debt, and in particular to the relation between currency and output risk notwithstanding the vulnerability of debt positions to exchange rate devaluations. As external debt is usually denominated in hard currencies, whether GDP or export indexation can provide insurance against exchange rate risk is a relevant issue to address.

In what follows, we try to fill these gaps focusing in the next section on the type of indexation and then presenting a model of debt stabilization to empirically assess the insurance benefits that different types of indexation may offer to low income countries.

\section{CHOOSING THE TYPE OF INDEXATION}

The relevant feature of indexed loans, independently of whether they are indexed to GDP, exports or commodity prices, is that their cash flows - coupons, principal or both - are linked to the borrower's ability to pay; they imply lower payments in times of output contractions, export shortfalls or terms of trade shocks, that is, precisely when a country struggles to repay its debt.

Different types of indexed bonds have been proposed in the literature which vary depending on the reference variable to which payments are linked, their indexation method, and the type of index. However, since not all types of indexed bonds are equally suited for achieving the objectives suggested in the literature and, more importantly, not all of them will work if applied to non-marketable loans, a preliminary discussion of their characteristics and functioning is in order.

In what follows, we briefly consider the choice of the reference variable to which loans should be indexed that is closely intertwined with their currency denomination and, then, focus on the indexation scheme.

\section{Currency denomination}

The multilateral debt of low income countries is denominated in foreign currencies. As the resources available to MDBs are in hard currencies, it seems natural, at first sight, that they lend in United States dollars and special drawing rights (SDRs); if loans were denominated in local currencies, MDBs would have to bear the currency risk and additional hedging costs. It is however well known that foreign currency 
denomination is a major source of vulnerability for debtor countries, as exchange-rate depreciations increase the real burden of their debt and can make it unsustainable. This raises the issue of whether multilateral lenders should rather assume the currency risk and immunize debtor countries from the disruptive effects of exchange rate movements. Hausmann and Rigobon (2003) have argued that MDBs should lend to low income countries in their local currencies to help them redeem from the 'original sin'.

A possible explanation for why MDBs may insist on denominating their loans in hard currencies is to remove inflationary temptations. In principle, the problem could be solved by indexing domesticcurrency loans to the price level. However, if the incentive to monetize the debt is not fully removed and inflation leads to greater currency depreciation, then inflation-indexed debt fails to protect multilateral lenders from real exchange-rate depreciations. A second reason why multilateral debt is denominated in foreign currencies is to set incentives against 'competitive devaluations' (besides avoiding exposure to exchange-rate risk). While price indexation can provide an alternative to foreign currency denomination, inflation-indexed debt works as a discipline device only to the extent that a currency depreciation leads to higher inflation. These problems notwithstanding, it is worth exploring the potential of domestic currency loans in stabilizating the debt ratio.

\section{Reference variable}

The aim of indexed loans is to link the debt service of the borrowing country to its economic performance and therefore to its ability to pay. To this purpose, the GDP of a country is the most obvious indicator. There are, however, many other variables to which debt payments could be indexed; for example, the value of exports, tax revenues and key commodity prices. As regards to whether loans should be linked to nominal or real variables much depends on their currency denomination. Consider, for example, GDP indexation. If the loans are denominated in foreign currencies, say, United States dollars or SDRs, then a linkage to real GDP in local currency units is needed to prevent the issuing country from the doublecharge of balancing the inflation rate and paying for an associated depreciation of the local currency. On the other hand, if the loans were denominated in local currencies, they should be linked to nominal GDP (in local currency units) for two reasons. Firstly, linkage to nominal GDP would provide insurance to the borrower against unexpected deflation and thus help to stabilize the debt-to-GDP ratio. Secondly, as discussed before, nominal indexation would remove inflationary temptations and offer some protection to the lender against a depreciation of the exchange rate.

Finally, it is worth noting that, if the debt is denominated in foreign currencies, indexation to current dollar GDP is also a possibility. In fact, this type of indexation is studied in Ruban et al. (2008). It is, however, clear that the indexation of foreign currency debt to nominal GDP in dollars is equivalent to borrowing in domestic currency and indexing payments to nominal GDP in local currency units (except for the cross-currency devaluation effects that may arise if the foreign currency debt is not entirely denominated in dollars).

Another possibility is to link debt payments to the value (in dollars) of exports of goods and services. A linkage to nominal exports is justified by two reasons. First, data on exports are more difficult to manipulate and more timely measured than GDP. Second, they are the main source of foreign exchange needed to service the country's external debt obligations.

In our analysis we shall examine three types of indexation: (i) foreign currency loans indexed to real GDP in local currency units; (ii) foreign currency loans indexed to the dollar value of exports; and (iii) inflation-indexed loans denominated in local currencies. Instead, we do not consider indexation to specific commodity prices since this solution is appealing only to countries with particular export structures while we are interested in a reform of multilateral lending that could possibly apply to the largest number of low income countries. 


\section{A. Indexing method}

The issue of how bonds or loans should be indexed is rarely addressed in literature. Indeed, proposals of introducing GDP indexation have, so far, paid scant attention to the implications of alternative indexing methods. In this section, we try to fill the gap by discussing how alternative schemes perform in enhancing the sustainability of low income countries' debts. We first focus on bonds, since they are more easy to understand and then extend our considerations to non-marketable loans. For simplicity, we refer to bonds indexed to GDP, but our analysis equally applies to other reference variables.

While there are many variants of indexed bonds, they fall into two main categories: capital indexed bonds and interest indexed bonds. The way they work is as follows.

\section{Capital indexed bonds}

Capital indexed bonds have the principal linked to GDP. Therefore all payments (coupons and principal redemption) are adjusted to the accumulated growth of GDP from the time of issuance to the payment date. For instance, the interest payments are obtained by applying the fixed coupon to the principal multiplied by the ratio of the most recent value of GDP to the value of GDP at the time of issuance. The redemption payment is also adjusted to the accumulated growth over the time to maturity as follows:

$$
\begin{aligned}
& \text { Interest Payments }=r_{0} D_{0} \frac{G D P_{t}}{G D P_{0}} \\
& \text { Redemption Payment }=D_{0} \frac{G D P_{t}}{G D P_{0}}
\end{aligned}
$$

where $r_{0}$ is the fixed coupon, $D_{0}$ is the principal, the period $t$ refers to the date of the coupon payment, 0 indicates the time of issuance and $T$ the maturity date.

Capital indexed bonds are well understood since the indexing method is the same as that applied for inflation-indexed bonds currently issued in the United States and other advanced economies. A key feature of such bonds is that all payments are symmetrically linked to GDP developments and thus can be above or below par, though the contract could require a minimum redemption equal to par value (see Schröder et al., 2004, 2007). ${ }^{6}$ The Shiller's (1993) proposal of selling perpetual claims on a fraction of a country's GDP can be viewed as a special case of Capital indexed bonds with infinite maturity and coupons adjusted each year in response to the cumulated growth up to that year.

\section{Interest indexed bonds}

Interest-indexed bonds are bonds with coupons augmented with the growth rate of GDP. Specifically, they bear a floating coupon rate equal to the sum of a fixed rate and a variable component equal to the growth rate of GDP (above a baseline growth rate) over the entitlement period of the coupon (or over the most recent period for which data are available). Thus, coupons are adjusted each period in response to the growth of GDP in that period alone. A minimum coupon rate equal to zero is required to avoid negative interest payments. Redemption is at par, i.e. the redemption payment is equal to the principal. In formulae:

$$
\begin{gathered}
\text { Interest Payments }=\max \left[r_{0}+g_{t}-g^{*} ; 0\right] D_{0} \\
\text { Redemption Payment }=D_{0}
\end{gathered}
$$

\footnotetext{
${ }^{6}$ However, variants of capital indexed bonds where only interest payments are indexed to GDP have also been considered in the literature.
} 
where $g_{t}$ is the growth rate of GDP over the period between the current and the previous interest payment and $g^{*}$ denotes the baseline growth rate of GDP specified in the contract prior to the bond's issue.

This indexation scheme is that originally proposed by Borensztein and Mauro (2004), but various types of interest-indexed bonds have been considered in the literature (see e.g. Ruban et al., 2008). The main differences arise because of the introduction of minimum and/or a maximum coupon rates, that is, floors or caps to interest payments. ${ }^{7}$ In fact, a more general specification for the coupon payment is

$$
\text { Interest Payments }=\min \left\{r^{c} ; \max \left[r_{0}+g_{t}-g^{*} ; r^{f}\right]\right\} D_{0}
$$

where $r^{c}$ and $r^{f}$ denotes the maximum (cap) and minimum (floor) coupon rates, respectively.

If negative payments were allowed, the precise setting of the fixed-rate component of the coupon and the baseline growth rate would be of little or no consequence. Indeed, if the market were perfect, alternative choices of these parameters would just affect pricing; i.e. they would translate into deviations of issuance price above or below par. However, insofar as negative payments are infeasible, the difference between the fixed rate and the baseline growth rate determines the extent of insurance that such bonds provide against a fall in GDP growth. A high fixed rate and a low baseline growth rate are needed for insurance, since growth rates lower than $g_{m_{1}}=-\left(r_{0}-g^{*}\right)$ would have no effects on interest payments (as well as on the redemption value). This unpleasant implication of interest indexed bonds is exacerbated by the presence of a minimum coupon rate, $r^{f}$, since the floor below which the growth rate becomes irrelevant is raised to $g_{m_{2}}=r^{f}-\left(r_{0}-g^{*}\right)$. The issuance of interest indexed bonds can be viewed as the sale of a call option on GDP growth. As a premium is paid by investors, the expected cost of debt service decreases but the relief that the borrower obtains for very bad realizations of GDP is limited.

\section{B. Choosing the indexation scheme for MDB loans}

There is a main difference between Interest indexation and capital indexation. With Interest indexation, GDP fluctuations substantially change the flow of interest payments while leave the redemption or the amortization payments unaffected, whereas with Capital indexation such payments adjust to the level of GDP that has instead a small impact on interest payments. Hence, the insurance that an interest-indexed scheme provides is front loaded and comes earlier than needed, i.e. before debt redemption, while, with capital indexation, insurance is back loaded and works by adjusting the principal or amortization payments to the borrower's capacity to pay. This makes capital indexation particularly suited for 40-year IDA loans which pay a service charge of only 0.75 per cent, and have a back-loaded repayment profile: after an initial grace period of 10 years, 2 per cent of the IDA loan is repaid in each of the following 10 years, and a yearly 4 per cent over the remaining twenty years.

These considerations suggest that capital-indexed loans are a better hedge against the repayment difficulties that low income countries may encounter due to the unsatisfactory performance of their economies. As discussed in the previous section, the requirement of non-negative interest payments imposes a further limitation to the insurance that interest-indexed loans provide against a substantial fall in GDP; debt service would be insensitive to large negative realizations of GDP, that is, exactly when relief is most valuable. Although, in principle, the problem could be solved by setting a sufficiently high fixed-rate component for the coupon, this solution runs against the concessionality of multilateral loans. The alternative of

\footnotetext{
${ }^{7}$ Other differences mainly concern the continuity and elasticity of payments with respect to changes in economic growth (see Borensztein and Mauro, 2004).
} 
providing further transfers to countries experiencing severe output contractions also seems unpractical. Capital-indexed loans offer a better insurance against extreme events in that capital indexation makes debt service payments a continuous function of GDP.

A further advantage of capital indexed loans is that they link the debt service to the development of GDP and thus to the borrower's ability to pay, whereas payments on interest-indexed loans do not necessarily conform with the borrower's paying ability, as the interest payments might turn quite high in a recovery from a recession while in fact the GDP has decreased since the date of issuance. To the extent that ensuring debt sustainability is a main concern in lending to low income counties, adjusting the debt burden to their ability to pay is a valuable feature of capital indexed loans. On the other hand, interest indexed loans are better instruments for counter-cyclical fiscal policy. Their interest payments help to stabilize the government budget against output fluctuations and provide 'fiscal space' for counter-cyclical policy during downturns. ${ }^{8}$

Hence, the choice of the indexing method hinges on the policy goal that is aimed for. To the extent that insurance and debt sustainability are more important objectives for low income countries than limiting the pro-cyclicality of their fiscal policies, capital indexed loans should be preferred to interest indexed loans.

\section{Indexed MDB loans: a proposal}

The introduction of capital indexation on non-marketable loans is not straightforward. Since GDP growth is expected to be positive and, in most countries, substantial, the interest and amortization payments on loans linked to the accumulated growth of GDP will rise, on average, well above their par implying a substantial increase in debt service compared to conventional loans. In the case of marketable bonds, this would not be a problem since positive expected growth would be priced in by the market and thus accounted for in an issuance price above the par value. By contrast, loans cannot rely on a market mechanism; their contract has to be properly designed to account for the expected accumulated growth and thus higher payments. Since the interest rate on concessional loans is already close to zero, a possible solution is to increase the amount disbursed for any given value of the principal. An equivalent but better solution is to index the interest and amortization payments to GDP relative to a baseline GDP. Hence, we propose the following indexing method:

$$
\begin{gathered}
\text { Interest Payments }=r_{0} L_{0} \frac{G D P_{t}}{G D P_{t}^{*}} \\
\text { Amortization Payments }=\alpha_{t} L_{0} \frac{G D P_{t}}{G D P_{t}^{*}}
\end{gathered}
$$

where $r_{0}$ is the fixed coupon rate (the fixed component of the interest rate), $L_{0}$ is the principal of the loan (the amount disbursed), $\alpha_{t} \geq 0$ is the fraction of the loan repaid in period $t$, and where GDP $P_{t}^{*}$ indicates the baseline level of GDP.

It is worth noting that the baseline GDP level, $G D P_{t}^{*}$, is specified in the loan contract prior to the disbursement of the loan, say, at period 0 , for all future periods $t$ until the last payment on the loan. Thus, the baseline series of GDP has to be agreed upon by the two contracting parties, the MDB and the recipient country. It is then natural, though not necessary, to think that the MDB and the borrowing country set the baseline levels of GDP equal to its expected levels. They could agree upon the expected

\footnotetext{
${ }^{8}$ It is, however, worth noting that for interest-indexed debt to work as an automatic stabilizer, the delay in the release of GDP data should not be too long, otherwise this might lead to a situation in which payments are still high while in fact the economic circumstances have already deteriorated.
} 
annual growth rate of GDP over the repayment period of the loan and use this growth rate to derive the baseline series of GDP.

As the loan payments decrease with the specification of baseline growth, the drawing of an indexed contract may encounter serious difficulties. In particular, we expect the borrowing country to strongly bargain over baseline growth in order to obtain more favourable conditions. Multilateral loans are immune from the pricing difficulties which are major obstacle for the introduction of indexed bonds, but are sensitive to the contract design. The implementation of indexed loans requires that the MDB and the borrowing country agree upon the terms of the contract which may give rise to bargaining difficulties and lead to lengthy negotiations. ${ }^{9}$ We return to this issue in section IX.

\section{THE NEED FOR INSURANCE: STYLIZED FACTS}

A natural starting point to study the benefits of the three types of indexed loans, and their role in stabilizing the debt-to-GDP ratio, is to look at the volatilities of the growth rates of GDP, exports and the real exchange rate. Sudden changes in such variables may determine large variations in the debt-to-GDP ratio that make debt sustainability at risk. Evidence on the relative volatilities of GDP, exports and the real exchange rate may thus provide some preliminary indication of the main causes of debt vulnerability and the need for insurance.

Table 1 shows the standard deviations of the yearly growth rates of real GDP in local currency, of the dollar value of exports, and of the real exchange rate (more precisely, the dollar deflator) for 64 IDA countries and 31 high income OECD countries. The volatility of GDP growth for the IDA group is 5.4 per cent while it is only 2.9 per cent for OECD economies. Although it is well known that developing countries have a more unstable rate of GDP growth, the volatility of GDP growth in IDA countries is sizeable; it is almost two times that of industrialized countries. Interestingly, GDP growth appears to be more volatile in highly indebted countries, as shown by its 0.5 correlation with the debt-to-GDP ratio in 1999 (before the start of the enhanced HIPC initiative). Hence, it appears that the need for insurance is stronger at high levels of debt.

The volatility of the growth rate of the dollar value of exports is even larger; the standard deviation of export growth in the IDA group is 20.8 per cent, three times higher than the 6.7 per cent exhibited by OECD countries. This result does not depend on the presence of outliers, as shown by the maximum standard deviation and a median volatility only slightly lower than the average. Since exports are the main source of foreign exchange needed to service the external debt, their uncertainty exposes IDA countries to the risk of debt distress. However, export volatility is only weakly correlated with the debt ratio. Although insurance against export risk would clearly benefit low income countries, the most indebted would not gain more than the others.

IDA countries are also exposed to exchange rate risk because of the foreign currency denomination of their debts. Since their debt is in foreign currencies, their capacity to pay depends, not on the value of their GDP in constant local currency units, but on their GDP in current United States dollars. This implies that changes in the dollar deflator of GDP, i.e. in the real exchange rate, are destabilizing; their wealth effects are a major cause of debt vulnerability and crises. Table 1 shows that the rate of depreciation of the real exchange rate in IDA countries is 10 times more volatile than in OECD economies. Since this result is due to the presence of few episodes of hyper-devaluations, we computed the average standard deviation excluding three outliers. ${ }^{10}$ Despite this correction, the average volatility of the real exchange rate

\footnotetext{
9 The specification of baseline growth is a minor problem in the case of marketable bonds because different values for baseline growth would be adjusted by changes in their issuance price according to market expectations of future growth.

${ }^{10}$ We excluded Angola, the Democratic Republic of the Congo and Nicaragua.
} 
Table 1

VOLATILITY OF GROWTH RATES: GDP, EXPORTS AND REAL EXCHANGE RATES

\begin{tabular}{|c|c|c|c|c|c|c|}
\hline & \multirow{2}{*}{$\begin{array}{c}\text { IDA } \\
\text { countries } \\
\text { Average sta }\end{array}$} & \multirow{2}{*}{$\begin{array}{c}\text { OECD } \\
\text { countries } \\
\text { d deviations }\end{array}$} & \multicolumn{2}{|c|}{ IDA countries } & \multicolumn{2}{|c|}{ IDA countries } \\
\hline & & & Min. & Max. & $\begin{array}{c}\text { Corr. } \\
\text { with debt }\end{array}$ & $\begin{array}{l}\text { Rank corr. } \\
\text { with debt }\end{array}$ \\
\hline \multirow[t]{2}{*}{ GDP growth } & 5.4 & 2.9 & 0.8 & 31.8 & 0.53 & 0.27 \\
\hline & $(3.8)$ & $(2.3)$ & & & & \\
\hline \multirow[t]{2}{*}{ Exports growth } & 20.8 & 6.7 & 7.2 & 49.6 & 0.21 & 0.04 \\
\hline & $(19.2)$ & $(6.3)$ & & & & \\
\hline RER dep. & 103.5 & 9.3 & 2.2 & 4512.1 & 0.23 & 0.55 \\
\hline \multirow[t]{2}{*}{ Without outliers } & 17.6 & 9.3 & 2.2 & 74.3 & 0.49 & 0.49 \\
\hline & $(16.7)$ & $(9.3)$ & & & & \\
\hline \multirow[t]{2}{*}{ GDP nom. \$ growth } & 14.9 & 10.7 & 4.2 & 30.1 & & \\
\hline & $(14.4)$ & $(10.6)$ & & & & \\
\hline
\end{tabular}

Note: Country averages of standard deviations. Median in parenthesis.

remains high at 17.6 per cent, twice as large as in OECD economies. Highly indebted countries appear to be particularly exposed to real exchange-rate risk, since its correlation with the debt ratio is almost 0.5 . Hence, in countries with original sin, not only the real exchange rate matters for debt service, but it also tends to be significantly more volatile and the more so at high levels of debt.

It can however be argued that the GDP in current United States dollars is a more relevant indicator of a country's ability to pay. If the real exchange-rate depreciates at times of high real GDP growth, then the volatility of GDP growth in current United States dollars would be lower than the sum of the volatilities of its two components. Table 1 shows that this is indeed the case. If we exclude countries with hyperdevaluation episodes, the GDP growth in dollars is even more stable than the rate of real depreciation. However, the volatility of dollar GDP remains sizeable, 14.9 per cent, almost the same as that of the real exchange rate, 17.6 per cent. This finding suggests that the interaction between GDP-risk and currency risk deserves a particular attention.

We have so far examined the uncertainty of GDP, exports and the real exchange rate over one year which is a very short time horizon from the perspective of debt sustainability. In fact, it can be argued that the yearly volatilities of such variables do not matter much for the LICs' capacity to pay since the debt they owe to multilateral creditors is very long term. To shed some light in this issue, table 2 reports the average growth rates of GDP and exports, and the rate of depreciation of the real exchange rate of IDA countries for two separate periods, between 1990 and 2000 and between 2000 and 2010. The result is striking: for a large number of countries there is a huge difference between the average growth rates in the two subperiods. Once viewed from a long-term perspective, the uncertainty surrounding the LICs' capacity to pay is even worse than what the yearly volatilities may show. This evidence suggests that the performance of such countries over a long future horizon is very difficult to predict on the basis of their historical experience, and raises doubts on the reliability of the debt sustainability analysis (DSA) as a way to decide which countries are worth receiving large loans and which should instead obtain small grants, as it currently happens for IDA assistance under the DSF. Indeed, this evidence suggests that LICs are particularly vulnerable to unexpected events which play a major role in determining their debt sustainability. Then, the analysis should focus on the unanticipated variability of GDP, exports, the real exchange rate and their relations over long future horizons, as we do in what follows. 
Table 2

AVERAGE GROWTH RATES: 1990-2000 VERSUS 2000-2010

\begin{tabular}{|c|c|c|c|c|c|c|}
\hline & \multicolumn{2}{|c|}{ GDP growth } & \multicolumn{2}{|c|}{ Export growth } & \multicolumn{2}{|c|}{$R E R$ depreciation } \\
\hline & 1990-2000 & 2000-2010 & 1990-2000 & $2000-2010$ & $1990-2000$ & 2000-2010 \\
\hline Angola & 1.2 & 11.4 & 12.3 & 24.5 & -78.5 & -15.1 \\
\hline Bangladesh & 4.9 & 5.8 & 14.7 & 12.1 & -0.3 & -2.0 \\
\hline Benin & 4.7 & 4.0 & 6.8 & 12.8 & 3.7 & -6.6 \\
\hline Bhutan & 5.5 & 8.5 & n.a. & n.a. & 1.2 & -4.5 \\
\hline Burkina Faso & 4.8 & 5.7 & 4.8 & 19.0 & 6.1 & -6.4 \\
\hline Burundi & -1.4 & 3.2 & 0.3 & 17.5 & 3.1 & -5.4 \\
\hline Cambodia & 7.5 & 8.1 & 27.8 & 14.6 & 2.4 & -3.7 \\
\hline Cameroon & 0.8 & 3.3 & 2.0 & 8.8 & 3.0 & -4.4 \\
\hline Central African Rep. & 1.4 & 1.0 & -2.8 & n.a. & 6.6 & -6.2 \\
\hline Chad & 1.9 & 8.9 & 0.8 & n.a. & 4.0 & -9.1 \\
\hline Comoros & 1.5 & 2.1 & 6.2 & n.a. & 2.3 & -7.6 \\
\hline Congo (the) & 1.4 & 4.7 & 9.1 & 14.3 & -1.4 & -9.5 \\
\hline Côte d'Ivoire & 2.0 & 1.2 & 3.6 & 11.7 & 3.5 & -6.5 \\
\hline Democratic Republic of the Congo & -5.6 & 4.8 & n.a. & n.a. & 1815.0 & -10.9 \\
\hline Djibouti & -1.8 & 4.0 & 0.1 & 8.3 & -3.9 & -3.4 \\
\hline Eritrea & 5.4 & 1.0 & 9.2 & n.a. & 1.4 & -12.3 \\
\hline Ethiopia & 3.0 & 8.5 & 4.3 & 17.4 & 9.0 & -5.5 \\
\hline Gambia, The & 3.3 & 3.9 & 5.6 & 10.1 & -0.3 & -2.0 \\
\hline Ghana & 4.2 & 5.8 & 10.5 & 14.9 & 7.6 & -15.7 \\
\hline Guinea & 4.1 & 2.8 & 1.0 & 8.8 & 1.8 & 0.9 \\
\hline Guinea-Bissau & 2.5 & 1.3 & 21.8 & 14.2 & 2.9 & -15.4 \\
\hline Guyana & 4.2 & 2.5 & 4.3 & 5.8 & 0.9 & -10.8 \\
\hline Haiti & 0.0 & 0.2 & 21.2 & 5.3 & 0.8 & -5.7 \\
\hline Honduras & 3.0 & 4.1 & 14.0 & 6.4 & -3.5 & -3.9 \\
\hline Kenya & 2.1 & 4.1 & 6.0 & 12.8 & -0.7 & -5.1 \\
\hline Kiribati & 3.5 & 1.1 & 16.4 & n.a. & -5.8 & -6.4 \\
\hline Kyrgyzstan & -2.6 & 4.1 & 8.3 & 17.4 & -2.8 & -8.4 \\
\hline Lao People's Democratic Republic & 6.2 & 7.2 & 19.2 & 18.0 & 0.7 & -7.6 \\
\hline Lesotho & 4.2 & 13.5 & 10.5 & 13.9 & -0.4 & -0.8 \\
\hline Liberia & 3.4 & 1.8 & n.a. & 8.2 & 22.0 & -4.8 \\
\hline Madagascar & 1.9 & 2.8 & 9.5 & 2.8 & -1.6 & -4.8 \\
\hline Malawi & 3.9 & 4.7 & 5.4 & 14.7 & 6.4 & -7.6 \\
\hline Maldives & 8.3 & 7.8 & 11.0 & 10.1 & -1.1 & -4.4 \\
\hline Mali & 3.5 & 5.6 & 6.5 & 15.4 & 4.2 & -7.9 \\
\hline Marshall Islands & 1.3 & 1.8 & n.a. & n.a. & n.a. & n.a. \\
\hline Mauritania & 2.5 & 4.1 & -1.9 & n.a. & 1.8 & -8.9 \\
\hline Micronesia (Federated States of) & 2.7 & 0.2 & n.a. & n.a. & n.a. & n.a. \\
\hline Mongolia & -0.2 & 6.5 & -0.6 & 20.5 & 41.9 & -11.5 \\
\hline Mozambique & 5.1 & 7.9 & 12.3 & 16.8 & -0.5 & 0.1 \\
\hline Myanmar & 6.8 & 12.1 & 23.0 & 15.3 & n.a. & n.a. \\
\hline Nepal & 5.0 & 3.9 & 12.9 & 2.8 & 1.3 & -5.8 \\
\hline Nicaragua & 3.1 & 3.4 & 12.3 & 13.1 & -142.4 & -1.9 \\
\hline Niger (the) & 1.6 & 4.6 & -0.8 & 15.4 & 4.6 & -6.6 \\
\hline Nigeria & 3.3 & 6.4 & 13.3 & 17.2 & -1.5 & -8.9 \\
\hline Republic of Moldova & -8.4 & 5.2 & 1.9 & 14.5 & -7.7 & -10.3 \\
\hline Rwanda & 2.6 & 7.6 & 3.8 & 20.4 & 3.9 & -4.9 \\
\hline Samoa & 1.9 & 3.0 & 7.0 & 11.0 & -7.1 & -5.5 \\
\hline Sao Tome \& Principe & n.a. & 6.3 & 4.7 & 5.7 & n.a. & -5.0 \\
\hline Senegal & 2.8 & 4.1 & 1.5 & 10.6 & 5.7 & -5.9 \\
\hline Sierra Leone & -3.5 & 9.7 & -2.9 & 24.5 & 1.5 & -2.0 \\
\hline Solomon Islands & 2.7 & 3.7 & 3.8 & 16.5 & -1.1 & -0.8 \\
\hline Sudan & 4.8 & 6.4 & 13.9 & 23.0 & 15.5 & -10.5 \\
\hline Tajikistan & -7.7 & 8.4 & n.a. & 10.8 & -7.3 & -12.3 \\
\hline Togo & 2.3 & 2.6 & -0.6 & 12.7 & 4.5 & -5.9 \\
\hline Tonga & 2.4 & 1.1 & -2.6 & 9.3 & -3.0 & -5.0 \\
\hline Tuvalu & 3.3 & 2.0 & n.a. & n.a. & -1.5 & -5.8 \\
\hline Uganda & 6.5 & 7.4 & 12.2 & 18.8 & 9.0 & -3.0 \\
\hline United Republic of Tanzania & 3.4 & 7.0 & 9.8 & 17.3 & -4.6 & -1.4 \\
\hline Vanuatu & 4.2 & 3.2 & 10.7 & 5.9 & -1.7 & -6.1 \\
\hline Yemen & 5.6 & 3.9 & 13.8 & 10.8 & -0.8 & -8.4 \\
\hline Zambia & 0.7 & 5.6 & -8.5 & 27.3 & 5.6 & -10.7 \\
\hline
\end{tabular}




\section{A MODEL OF INDEXED DEBT AND DEBT SUSTAINABILITY}

Multilateral loans either indexed to GDP, or exports or denominated in domestic currency can reduce LICs' vulnerability to adverse shocks to GDP, the exchange rate and net exports that threaten their debt sustainability. In this section, we present a simple model where indexed loans may help to stabilize the debt ratio and thus reduce the likelihood of a debt crisis. The aim of the MDBs and the IDA countries is to ensure the sustainability of the external debt. This is accomplished, according to DSA, by implementing the necessary actions and lending strategies to maintain the debt-to-GDP ratio within a threshold limit $B^{T}$ that varies across IDA countries depending on the quality of their policies and institutions, as measured by the CPIA. To this end, a strategy is decided taking into account debt repayments and the possible realizations of output, inflation, the exchange rate, the current account and foreign direct investment (FDI) flows as outlined in stress test scenarios. The outcome of these efforts is however uncertain since unforeseeable events, i.e. bad shocks $Z$, could still put the external debt on an unsustainable path. A debt distress (or crisis) materializes if the debt-to-GDP ratio, $B_{t+1}$, exceeds the threshold level:

$$
B_{t+1}=\hat{B}_{t+1}+Z>B^{T}
$$

where $Z$ is a shock due to unforeseeable events, $\hat{B}_{t+1}$ is the debt ratio prior to the shock, and $B^{T}$ is the threshold level of the debt. Alternatively, $Z$, can be viewed as a shock to the current account, net transfers or FDI that occurs after the stabilization programme has been carried out, as discussed below, or as a debt increase due to the discovery of hidden liabilities.

The objective of the MDB and the IDA country is to minimize the probability that the debt becomes unsustainable, that is, that the debt-to-GDP ratio exceeds the threshold level, $B^{T}:{ }^{11}$

$$
\operatorname{Min} E_{t} \operatorname{Prob}\left[Z>B^{T}-\hat{B}_{t+1}\right]=\operatorname{MinE}_{t} \int_{B^{T}-\hat{B}_{t+1}}^{\infty} \Phi(Z) d z
$$

where $\Phi(Z)$ is the probability density function of $Z$, and $E_{\mathrm{t}}$ denotes expectations conditional on the information at time $t$.

The debt increases because of the interest payments on the outstanding debt minus the net-of-interest current account and the inflow of (non-creating debt) foreign direct investment. The evolution of the debt ratio also depends on the type of loans, on whether they are indexed or not, denominated in foreign or domestic currency. Consider, first, the case of conventional loans. As the latter bear a fixed interest rate and are denominated in SDRs or United States dollars, the debt ratio decreases with real GDP growth, $g$, and the growth rate of the dollar GDP deflator, $\pi-e$, i.e. with a real exchange-appreciation (assuming a zero foreign inflation). Hence, the dynamics of the debt ratio can be linearly approximated as:

$$
B_{t+1}=\hat{B}_{t+1}+Z=\left(1+r+e_{t+1}-\pi_{t+1}-g_{t+1}\right) B_{t}-n x_{t+1}+Z
$$

where $r$ is the fixed interest rate set at time $t, e_{t+1}$ is the rate of depreciation of the exchange rate, $\pi_{t+1}$ is the inflation rate, $g_{t+1}$ is the growth rate of real GDP, and $n x_{t+1}$ is the ratio of net exports to GDP. Note that we have set net transfers and FDIs equal to zero because they are not systematically correlated

\footnotetext{
11 Alternatively, the problem could be modelled by, first, deriving the optimal adjustment to the deviation of the debt ratio from its threshold level and, then, by considering the ex-ante choice of the debt instrument. The analysis of the extended problem is not carried out since its implications for debt management are the same.
} 
with the other variables in the model. Alternatively, we may think that $Z$ subsumes shocks to net transfers and FDIs.

In what follows we study the role of indexed loans and compare their performance with that of conventional loans in minimizing the probability that the debt ratio exceeds its threshold level.

The first type of instruments we consider are loans indexed to real GDP and denominated in foreign currency. GDP-indexed loans have payments indexed to the ratio of real GDP to its baseline level GDP*, as discussed in section IV.C. If the whole debt is indexed to GDP, its ratio evolves as:

$$
B_{t+1}=\left(1+r^{\gamma}+e_{t+1}-\pi_{t+1}-g_{t+1}\right) B_{t} \frac{G D P_{t+1}}{G D P_{t+1}^{*}}-n x_{t+1}+Z
$$

where $r^{\gamma}$ is the fixed rate component of the interest rate. Noting that the ratio $G D P_{\mathrm{t}+1} / G D P_{\mathrm{t}+1}^{*}$ can be $\log$-linearized as $1+\ln \left(G D P_{t+1}\right)-\ln \left(G D P_{t+1}^{*}\right)$ and assuming that baseline GDP is set equal to expected GDP, the debt ratio is equal to

$$
B_{t+1}=\left(1+r^{\gamma}+e_{t+1}-\pi_{t+1}-g_{t+1}\right)\left(1+g_{t+1}-E_{t} g_{t+1}\right) B_{t}-n x_{t+1}+Z
$$

where $g_{t+1}=\ln \left(G D P_{t+1}\right)-\ln \left(G D P_{t}\right)$ is the accumulated growth of GDP between time $t$ and $t+1$.

Since MDBs' loans have a long time to maturity we are concerned with debt service payments and debt accumulation over a long horizon ahead. For instance, in the case of IDA loans with a 40-year maturity and an initial grace period of 10 years during which no principal payment is required, the relevant time

period should be, at least, 10 years. However, due to the unreliability of forecasts at horizon longer than 10 years, in the empirical analysis of the next section we shall focus on two forecast horizons: a 5-year and a 10-year horizon. Therefore, we make the strong simplifying assumption that equation (8) displays debt accumulation over such long horizons and accordingly interpret $g_{t+1}$ as the 5-year or 10-year growth rate of GDP.

If both types of debt, conventional and GDP-indexed, are outstanding, then the debt ratio is linearly approximated by

$$
B_{t+1}=\left(1+r+e_{t+1}-\pi_{t+1}-g_{t+1}\right)(1-\gamma) B_{t}+\left(1+r^{\gamma}+e_{t+1}-\pi_{t+1}-E_{t} g_{t+1}\right) \gamma B_{t}-n x_{t+1}+Z
$$

where $\gamma$ is the share of GDP-indexed debt chosen in period $t$.

\section{A. The choice of conventional versus GDP-indexed loans}

The objective of the MDB, and the IDA country, is to minimize the probability that the debt ratio exceeds its sustainable level, $B^{T}$, either because of unforeseeable events that lead to an unexpected increase in the debt ratio, or because of shocks to net transfers or FDIs. To this end, the MDB and the IDA country choose the share of GDP-indexed loans, $\gamma$, to minimize

$$
\operatorname{MinE}_{t} \operatorname{Prob}\left[Z>B^{T}-B_{t+1}\right]=\operatorname{MinE}_{t} \int_{B^{T}-\hat{B}_{t+1}}^{\infty} \Phi(Z) d z
$$

subject to the debt accumulation equation (10). 
Deriving (11) with respect to $\gamma$ yields

$$
E_{t}\left[\left(r^{\gamma}-r+g_{t+1}-E_{t} g_{t+1}\right) \Phi\left(B^{T}-\hat{B}_{t+1}\right)\right]=0
$$

where $r^{\gamma}-r$ is the eventual risk premium on GDP-indexed loans, $B^{T}-\hat{B}_{t+1}$ is the distance of the debt ratio from its sustainable threshold in the absence of shocks, $Z$, and $\Phi\left(B^{T}-\hat{B}_{t+1}\right)$ is a function of $\gamma$.

The first order condition (12) has a simple interpretation: it shows that the debt composition is optimal only if the opportunity cost of additional GDP-indexed lending is uncorrelated with the increase in the probability that debt stabilization fails. If this were not the case, the MDB could reduce this probability by changing the debt structure; e.g. it could substitute GDP-indexed loans for conventional loans or vice-versa. ${ }^{12}$

To gain further intuition, it is worth noting that the opportunity cost of GDP-indexed loans depends on the difference in the interest cost of GDP-indexed loans and conventional loans, $r^{\gamma}-r$, and the unanticipated growth rate of GDP, $g_{t+1}-E_{t} g_{t+1}$. If the latter turned out to be negative, GDP-indexed loans would cost less than conventional loans.

The difference between the expected interest cost of GDP-indexed loans and conventional loans, $r^{\gamma}-r$, depends on the MDB decision regarding the concessionality of GDP-indexed loans. As providing insurance is costly, the MDB may require a premium on such loans. This premium could however be small to the extent that GDP risk were uncorrelated across IDA countries and thus diversifiable in a portfolio of loans to such countries (see section VIII). Moreover, MDBs should trade off their greater exposure to GDP risk against the lower probability of repayment difficulties by IDA countries.

Finally, it is worth noting that equation (12) assumes that the baseline growth coincides with expected growth and that the MDB and the IDA country share the same expectations. If, for example, the IDA country expected a higher growth rate, i.e. $E_{t}^{I D A} g_{t+1}>E_{t} g_{t+1}$, then the perceived opportunity cost of servicing GDP-indexed debt would correspondingly increase to $r^{\gamma}-r+E_{t}^{I D A} g_{t+1}-E_{t} g_{t+1}$.

To derive an explicit solution for the optimal share, $\gamma^{*}$, of GDP-indexed debt we must specify the probability density function, $\Phi(Z)$. Since this function cannot be estimated, we take a linear approximation of $\Phi(Z)$ over the range of bad realizations, $Z>0$, of the shock. ${ }^{13}$ This implies a triangular probability density function equal to

$$
\Phi(Z)=\frac{\bar{Z}-Z}{\bar{Z}^{2}}
$$

where $\bar{Z}$ is the worst possible realization of the shock to debt accumulation, and $Z>0$. The triangular density is the linear approximation of any density function decreasing with $Z$ (for $Z>0$ ); it implies that bad realizations of the shock, $Z$, are less likely to occur the greater is their size.

\footnotetext{
12 The argument assumes that there are non-negative constraints to the choice of debt instruments.

${ }^{13}$ We assume that the strategy in the DSA is expected to stabilize the debt, so that $B^{T}>\hat{B}_{t+1}$.
} 
Substituting equations (13) and (10) in the first order condition (12) yields the optimal share of GDPindexed debt:

$$
\begin{aligned}
\gamma^{*}= & \frac{\operatorname{Var}\left(g_{t+1}\right)}{\operatorname{Var}\left(g_{t+1}\right)+\left(r^{\gamma}-r\right)^{2}}-\frac{\operatorname{Cov}\left(g_{t+1}\left(e_{t+1}-\pi_{t+1}\right)\right)}{\operatorname{Var}\left(g_{t+1}\right)+\left(r^{\gamma}-r\right)^{2}} \\
& +\frac{\operatorname{Cov}\left(g_{t+1} n x_{t+1}\right)}{\left[\operatorname{Var}\left(g_{t+1}\right)+\left(r^{\gamma}-r\right)^{2}\right] B_{t}}-\left(r^{\gamma}-r\right) \frac{\left[\bar{Z}-\left(B^{T}-E_{t} B_{t+1}^{\gamma=0}\right)\right]}{\left[\operatorname{Var}\left(g_{t+1}\right)+\left(r^{\gamma}-r\right)^{2}\right] B_{t}}
\end{aligned}
$$

where $\operatorname{Var}($.$) and \operatorname{Cov}($.$) denote variances and covariances conditional on the information available$ at time $t$, and $E_{t} B_{t+1}^{\gamma=0}$ is the expected debt-to-GDP ratio when the share of GDP-indexed debt, $\gamma$, is equal to zero.

The optimal share, $\gamma^{*}$, depends on both risk and cost considerations. GDP-indexed debt is a perfect hedge against variations in the debt ratio due to output fluctuations but, to stabilize the debt ratio, it must provide insurance against real exchange-rate risk and net exports uncertainty. This requires a negative conditional covariance of GDP growth with the real exchange rate and a positive covariance with net exports.

A positive covariance of GDP growth with next exports makes indexed loans an even better hedge as it implies lower debt payments when net exports are unexpectedly low. If the real exchange rate tends to depreciate when growth is unexpectedly low, GDP-indexed debt helps to stabilize the debt ratio and reduce the risk of a debt crisis. This is because the increased burden of dollar denominated debt is hedged by lower payments on indexed loans. The case for indexation instead weakens as the conditional variance of GDP growth increases, thus producing unnecessary fluctuations in interest payments.

While GDP-indexed debt offers an insurance against low growth and, possibly, real exchange-rate depreciation, it may cost more to IDA countries than conventional debt. If MDBs ask for a premium on indexed loans, $r^{\gamma}-r>0$, this leads, on average, to greater debt accumulation. Debt sustainability thus implies a trade off between cost and risk minimization. The presence of a risk premium on GDP-indexed debt reduces the optimal share of such debt, as shown by the last term in equation (14). The impact of the risk premium increases as the debt ratio, $B_{t+1}$ approaches its maximum sustainable level, $B^{T}$; the higher the probability of debt distress the greater the importance of expected cost minimization relative to insurance effects. In other words, insurance is more valuable to countries with a more sustainable borrowing strategy. Finally, a greater variance of GDP growth reduces the impact of the expected cost differential of GDP-indexed debt on its optimal share as much as it reduces the importance of hedging.

\section{B. The choice of conventional versus export-indexed loans}

Although loans indexed to GDP growth are the natural instruments to stabilize the debt ratio against output fluctuations, their implementation runs into various difficulties due to misreporting and measurement problems. This raises the issue of whether loans to IDA countries could be indexed to variables that can be measured more precisely while being still correlated, though imperfectly, to output growth. In light of these considerations, loans indexed to the growth rate of the value of exports (measured in dollars) may offer an alternative to GDP indexation that is worth exploring. In this section we study the role of export-indexed loans, advocated by Guillaumont et al. (2003) and compare their performance to that of conventional loans in minimizing the probability that the debt ratio exceeds its threshold level. In particular, we consider loans with payments indexed to the deviation of nominal-export growth from its baseline (expected) value. 
Defining with $v_{t+1}$ the growth rate of the value of exports, the payments on export-indexed loans can be linearly approximated (as in the case of GDP indexation) by $r^{x}+v_{t+1}-E_{t} v_{t+1}$, where $v_{t+1}$ is equal to the sum of export-price inflation and the growth rate of real export, and where the baseline growth rate, $E_{t} v_{t+1}$, is assumed to be equal to the expected growth rate.

If both types of debt, conventional and export-indexed, are outstanding, then the debt ratio is equal to

$$
\begin{aligned}
B_{t+1}= & \left(1+r+e_{t+1}-\pi_{t+1}-g_{t+1}\right)(1-x) B_{t}+ \\
& +\left(1+r^{x}+v_{t+1}-E_{t} v_{t+1}+e_{t+1}-\pi_{t+1}-g_{t+1}\right) x B_{t}-n x_{t+1}+Z
\end{aligned}
$$

where $x$ is the share of export-indexed debt chosen in period $t$.

The problem of the MDB and the IDA country is to choose the share of export-indexed loans $x$ to minimize the probability that the debt ratio exceeds its sustainable level, $B^{T}$, i.e. to minimize equation (11) subject to the debt equation (15).

Deriving (11) with respect to $x$ yields the following first order condition:

$$
E_{t}\left[\left(r^{x}-r+v_{t+1}-E_{t} v_{t+1}\right) \Phi\left(B^{T}-\hat{B}_{t+1}\right)\right]=0
$$

where $r^{x}-r$ is the eventual risk premium on export-indexed loans, $B^{T}-\hat{B}_{t+1}$ is the distance of the debt ratio from its sustainable threshold (with $Z=0$ ), and $\Phi\left(B^{T}-\hat{B}_{t+1}\right)$ is a function of $x$.

The first order condition (16) has the same interpretation as condition (12): it shows that the debt composition is optimal only if the opportunity cost of additional export-indexed lending is uncorrelated with the increase in the probability that debt stabilization fails. The opportunity cost of export-indexed loans depends on their expected interest-cost differential relative to conventional loans, $r^{x}-r$, and on the unanticipated growth of the value of exports, $v_{t+1}-E_{t} v_{t+1}$.

To derive an explicit solution for the optimal share, $x^{*}$, of export-indexed debt, we again rely on the triangular probability density function (13), that is, the linear approximation of the density function $\Phi(Z)$ over the range of bad realizations, $Z>0$, of the shock to debt accumulation.

Substituting equations (13) and (15) in the first order condition (16) yields the optimal share of exportindexed debt:

$$
\begin{aligned}
x^{*}= & \frac{\operatorname{Cov}\left(v_{t+1} g_{t+1}\right)}{\operatorname{Var}\left(v_{t+1}\right)+\left(r^{x}-r\right)^{2}}-\frac{\operatorname{Cov}\left(v_{t+1}\left(e_{t+1}-\pi_{t+1}\right)\right)}{\operatorname{Var}\left(v_{t+1}\right)+\left(r^{x}-r\right)^{2}} \\
& +\frac{\operatorname{Cov}\left(v_{t+1} n x_{t+1}\right)}{\left[\operatorname{Var}\left(v_{t+1}\right)+\left(r^{x}-r\right)^{2}\right] B_{t}}-\left(r^{x}-r\right) \frac{\left[\bar{Z}-\left(B^{T}-E_{t} B_{t+1}^{x=0}\right)\right]}{\left[\operatorname{Var}\left(v_{t+1}\right)+\left(r^{x}-r\right)^{2}\right] B_{t}}
\end{aligned}
$$

where $\operatorname{Var}($.$) and \operatorname{Cov}($.$) denote variances and covariances conditional on the information available$ at time $t$, and $E_{t} B_{t+1}^{x=0}$ is the expected debt-to-GDP ratio when the share of export-indexed debt, $x$, is equal to zero. 
The optimal share, $x^{*}$, depends on both risk and cost considerations. Export-indexed debt is clearly not as good a hedge against output fluctuations as GDP-indexed debt, but it may provide a better insurance against the risk of a fall in export or a real depreciation. To this end, export growth should be positively correlated to net exports and negatively correlated to unexpected movements in the real exchange rate. While the first condition is likely to hold in practice, the relation between exports and the exchange rate is uncertain and may depend on the country considered. For instance, if export growth is driven by productivity improvements or terms of trade effects that lead to an appreciation of the exchange rate, export indexation helps to stabilize the debt ratio. On the other hand, if export growth is due to an exchange-rate depreciation driven by capital outflows, then indexation may introduce an additional source of instability. The case for indexation also depends on the conditional variance of export growth; a high volatility of exports reduces the scope for insurance as it produces unnecessary fluctuations in interest payments.

As in the case of GDP indexation, a trade-off between risk and cost minimization emerges if the MDBs ask for a premium on export-indexed loans, that is, if $r^{x}-r>0$. As the expected interest cost of exportindexed loans exceeds that of conventional loans, the optimal share of indexed debt decreases, as shown by the last term in equation (17). The impact of the risk premium increases as the debt ratio, $B_{t+1}$ approaches its maximum sustainable level, $B^{T}$.

If the expected cost of repaying indexed loans is greater than that of conventional loans this may affect debt accumulation and thus the sustainability of the borrowing strategy. It is then crucial to assess whether MDBs are ready to extend the concessionality of conventional loans to indexed loans. This depends, among other factors, on the possibility for the MDBs to reduce their risk exposure by holding a diversified portfolio of loans.

\section{The choice of conventional versus domestic currency loans}

Because the debt of IDA countries is denominated in foreign currencies, exchange rate movements are a major cause of variation of the debt-to-GDP ratio. Hausmann and Rigobon (2003) have thus argued that MDBs should lend to low income countries in their local currencies to help them redeem from the 'original sin'. They also stress that domestic currency loans should be indexed to the price level to eliminate the debtor's temptation to inflate it away. If inflation nevertheless occurs and leads to a currency depreciation, price indexation can still protect the dollar value of MDBs' loans, but only to the extent that real exchange rate does not depreciates.

Although inflation indexation may not fully remove the incentives for opportunistic behaviour, it is worth comparing the performance of domestic currency loans to that of conventional loans in stabilizing the debt ratio.

The amortization payments in local currency of inflation-indexed loans are linearly approximated by $r^{h}+\pi_{t+1}$, where $r^{h}$ is the real interest rate. As it is standard practice with inflation indexed bonds, we do not link such payments to a baseline inflation rate. This implies that the real interest rate should be lower than the nominal rate on conventional loans, which could be problematic as the latter are highly concessional.

With both types of debt, conventional and inflation-indexed debt denominated in domestic currency, the debt ratio is equal to

$$
B_{t+1}=\left(1+r+e_{t+1}-\pi_{t+1}-g_{t+1}\right)(1-h) B_{t}+\left(1+r^{h}-g_{t+1}\right) h B_{t}-n x_{t+1}+Z
$$

Where $h$ is the share of inflation-indexed debt denominated in the local currency. 
The MDB and the IDA country choose the share of domestic currency debt $h$ to minimize the probability in equation (11) subject to the debt equation (15).

Deriving (11) with respect to $h$ yields the following first order condition:

$$
\left.E_{t}\left(r^{h}-r+\pi_{t+1}-e_{t+1}\right) \Phi\left(B^{T}-\hat{B}_{t+1}\right)\right]=0
$$

It is worth noting that, in this case, the interest rate differential, $r^{h}-r$, is not equal to the risk premium which is instead given by the expected return differential, $r^{h}+E_{t} \pi_{t+1}-E_{t} e_{t+1}-r$. Defining $\hat{r}^{h} \equiv r^{h}+E_{t} \pi_{t+1}-E_{t} e_{t+1}$, the first order condition (19) can be written as

$$
\left.E_{t}\left[\hat{r}^{h}-r+\left(\pi_{t+1}-E_{t} \pi_{t+1}\right)-\left(e_{t+1}-E_{t} e_{t+1}\right)\right] \Phi\left(B^{T}-\hat{B}_{t+1}\right)\right]=0
$$

which has the usual interpretation, and where $\Phi\left(B^{T}-\hat{B}_{t+1}\right)$ is a function of $h$.

Using the triangular probability density function (13) and equation (18) in the first order condition (20) yields the optimal share of domestic currency debt:

$$
\begin{aligned}
h^{*}= & \frac{\operatorname{Var}\left(e_{t+1}-\pi_{t+1}\right)}{\operatorname{Var}\left(e_{t+1}-\pi_{t+1}\right)+\left(\hat{r}^{h}-r\right)^{2}}-\frac{\operatorname{Cov}\left(\left(e_{t+1}-\pi_{t+1}\right) g_{t+1}\right)}{\operatorname{Var}\left(e_{t+1}-\pi_{t+1}\right)+\left(\hat{r}^{h}-r\right)^{2}}+ \\
& -\frac{\operatorname{Cov}\left(\left(e_{t+1}-\pi_{t+1}\right) n x_{t+1}\right)}{\left[\operatorname{Var}\left(e_{t+1}-\pi_{t+1}\right)+\left(\hat{r}^{h}-r\right)^{2}\right] B_{t}}-\left(\hat{r}^{h}-r\right) \frac{\left[\bar{Z}-\left(B^{T}-E_{t} B_{t+1}^{h=0}\right)\right]}{\left[\operatorname{Var}\left(e_{t+1}-\pi_{t+1}\right)+\left(\hat{r}^{h}-r\right)^{2}\right] B_{t}}
\end{aligned}
$$

where $\operatorname{Var}($.$) and \operatorname{Cov}($.$) denote variances and covariances conditional on the information available$ at time $t$, and $E_{t} B_{t+1}^{h=0}$ is the expected debt-to-GDP ratio when the share of domestic currency debt, $h$, is equal to zero.

Inflation-indexed debt denominated in local currency can stabilize the debt ratio against real exchangerate movements, as clearly shown by the first term in equation (21). If the latter were the only source of uncertainty, then providing loans in domestic currency would be optimal. However, output and exports uncertainty must also be considered. For instance, a positive covariance between the real exchange rate and net exports suggests a lower share of domestic currency loans. This is because a fall in exports due to a real appreciation would be better hedged by dollar denominated debt. On the other hand, a negative covariance between GDP growth and real depreciations strengthens the case for domestic currency debt. The latter would mostly benefit countries experiencing sudden stops and currency crises characterized by real depreciations and output contractions.

Finally, the optimal share of inflation-indexed loans in domestic currency decreases with their expected return differential with conventional loans, as shown by the last term in equation (21). This is because a greater cost of domestic currency loans increases debt accumulation and weakens the sustainability of the debt. Even if the MDBs were willing to extend the concessionality of conventional loans to domestic currency loans, the implementation of such a strategy could run into practical difficulties. In particular, to obtain the same expected return on both types of loans, the MDBs should set the interest rate on domestic currency loans equal to $r^{h}=r+E_{t} e_{t+1}-E_{t} \pi_{t+1}$. If the real exchange rate is expected to appreciate, this requires a negative real interest rate, $r^{h}$, given the low nominal rate, $r$, on conventional loans. More 
importantly, as the expected movements in the real exchange rate differ across IDA countries, they would be asked to pay different interest rates on the same loans, which can be politically infeasible.

\section{AN EMPIRICAL ASSESSMENT OF INSURANCE OPPORTUNITIES}

In this section, we empirically investigate whether multilateral loans indexed either to GDP, exports or inflation, may help to stabilize the debt-to-GDP ratio in IDA countries and thus enhance their debt sustainability. To this end, we evaluate the insurance that indexed loans can provide to a group of IDA countries through the estimation of the conditional variances and covariances of GDP growth, real exchange-rate depreciation and net exports (relative to GDP). The analysis aims to identify the optimal type of indexation by comparing the extent of hedging that the three types of indexed loans studied in the previous section can offer.

\section{A. Estimation strategy}

The theoretical model presented in section VI derives the optimal shares of indexed loans as functions of the variances and covariances of GDP growth, real exchange-rate depreciation and net exports over a long future horizon conditional on the information available at time $t$. More precisely, these variances and covariances represent the conditional second moments of the unanticipated components of future realizations of such variables.

Our empirical strategy is to recover the theoretical conditional variances and covariances from the estimation of the variances and covariances of forecast errors obtained from a vector autoregression (VAR) analysis of the relations between GDP growth, real exchange-rate depreciation and net exports. This approach appears particularly suitable in the present case for a number of reasons. First, the forecast errors capture both the deviation of the variable realization from the conditional mean (the forecast) and the error made in the forecast, for example, in estimating baseline GDP growth. Second, we are interested in the projected, out-of-sample, relations between the unanticipated components of the relevant variables. Third, we are interested in estimating such relations over a long future horizon, since IDA loans have a long maturity, typically of 40 years. Fourth, this approach is consistent with the stress tests of DSAs, but, unlike the latter that consider each shock separately, it captures the stochastic relations between shocks as estimated from VAR analysis.

The strategy used to estimate the variances and covariances of the forecast errors relies on a Data Generating Process for the macroeconomic variables that follows a Vector Autoregressive (VAR) process of the form

$$
Y_{t}=A_{1} Y_{t-1}+\ldots+A_{p} Y_{t-p}+B_{0} X_{t}+\ldots+B_{p} X_{t-p}+\phi \mu_{t}+\varepsilon_{t}
$$

where $Y_{t}$ is the $k \times 1$ vector of dependent variables, $X_{t}$ is the $k \times 1$ vector of exogenous variables, $\mu_{t}$ contains deterministic components, and $\left(A_{1}, \ldots, A_{p}, B_{0}, \ldots, B_{p}, \phi\right)$ are matrices of parameters to be estimated. Finally, $\varepsilon_{t}$ is a vector of error terms with the usual assumption $\varepsilon_{t} \sim N(0, \Sigma)$.

The vector of endogenous variables contains the log of the real GDP (in local currency units), the log of the real exchange rate (i.e. the log of the reciprocal of the dollar deflator), the log of the dollar value of exports, and the ratio of net exports to GDP. The vector of exogenous variables, instead, contains the lagged United States long-term interest rate, the log of the real GDP of the OECD countries in the previous year, and the lagged debt-to-GDP ratio. Among the deterministic components we have considered a constant term and a linear trend. 
Given the presence of unmodelled exogenous variables, this kind of model is generally referred to VARX or dynamic simultaneous equations model (SEM). ${ }^{14}$

However, if the aim of the analysis is to forecast the dependent variables $Y_{t}$, and the future paths of the unmodelled variables are unknown to the forecaster, a simple and practical assumption is to model the exogenous variables $X_{t}$ as a $\operatorname{VAR}(q)$ process

$$
X_{t}=C_{1} X_{t-1}+\ldots+C_{q} X_{t-q}+\varphi v_{t}+v_{t}
$$

The two reduced form models for $Y_{t}$ and $X_{t}$ can thus be considered together in one overall model of the form

$$
\begin{gathered}
{\left[\begin{array}{cc}
I_{k} & -B_{0} \\
0 & I_{m}
\end{array}\right]\left(\begin{array}{l}
Y_{t} \\
X_{t}
\end{array}\right)=} \\
+\left[\begin{array}{cc}
A_{1} & -B_{1} \\
0 & C_{1}
\end{array}\right]\left(\begin{array}{l}
Y_{t-1} \\
X_{t-1}
\end{array}\right)+\ldots+\left[\begin{array}{cc}
A_{p} & -B_{p} \\
0 & C_{p}
\end{array}\right]\left(\begin{array}{l}
Y_{t-p} \\
X_{t-p}
\end{array}\right) \\
+\left[\begin{array}{cc}
\phi & 0 \\
0 & \varphi
\end{array}\right]\left(\begin{array}{l}
\mu_{t} \\
v_{t}
\end{array}\right)+\left(\begin{array}{l}
\varepsilon_{t} \\
v_{t}
\end{array}\right)
\end{gathered}
$$

where it is assumed, without loss of generality, that $p \geq q$ and, as a consequence, $C_{j}=0$ for $j>q$. Premultiplying by

$$
\left[\begin{array}{cc}
I_{k} & -B_{0} \\
0 & I_{m}
\end{array}\right]^{-1}=\left[\begin{array}{cc}
I_{k} & B_{0} \\
0 & I_{m}
\end{array}\right]
$$

gives a standard reduced form $\operatorname{VAR}(p)$ for $Z_{t}=\left(Y_{t}^{\prime}, X_{t}^{\prime}\right)^{\prime}$ as

$$
Z_{t}=\Pi_{1} Z_{t-1}+\ldots+\Pi_{p} Z_{t-p}+\eta D_{t}+u_{t}
$$

for which the discussion of forecasting $\operatorname{VAR}(p)$ processes applies. More precisely, the wold moving average decomposition for stable $\operatorname{VAR}(p)$ processes is defined as

$$
Z_{t}=\Phi_{0}\left(u_{t}+\eta D_{t}\right)+\Phi_{1}\left(u_{t-1}+\eta D_{t-1}\right)+\Phi_{2}\left(u_{t-2}+\eta D_{t-2}\right)+\ldots
$$

with $\Phi_{0}=I_{k+m}$ and $\Phi_{s}$ computed recursively according to

$$
\Phi_{s}=\sum_{j=1}^{s} \Phi_{s-j} \Pi_{j} \quad \text { for } \quad s=1,2, \ldots
$$

whereby $\Pi_{j}=0$ for $j>p$. Given the two representations for the stochastic process $Z_{t}$, forecasts for horizons $h \geq 1$ can be generated recursively according to

${ }^{14}$ For a detailed discussion of these models, see Lütkepohl (2005), chapter 10. 


$$
Z_{t+h \mid t}=\Pi_{1} Z_{t+h-1}+\ldots+\Pi_{p} Z_{t+h-p}+\eta D_{t+h}
$$

where $Z_{t+j \mid t}=Z_{t+j}$ for $j \leq 0$, while the forecast error covariance or MSE matrix can be obtained as

$$
\Sigma_{z}(h)=\sum_{i=1}^{h-1} \Phi_{i} \Sigma_{u} \Phi_{i}^{\prime}
$$

where $\Sigma_{u}$ is the covariance matrix of the error term $u_{t}$.

The first $(k \times k)$ block elements of $\Sigma_{z}(h)$ are the variances and covariances of the unanticipated components of the endogenous variables $Y_{t+h \mid t}$ at different horizons $h$.

We have estimated a VAR model for each IDA country and used the variances and covariances of the forecast errors at the 5- and 10-year horizons as an estimate of the conditional variances and covariances of accumulated GDP growth, real exchange-rate depreciation and net exports. ${ }^{15}$

\section{B. Estimation results}

To estimate the conditional variances and covariances in equations (14), (17) and (21), we use the covariances of the forecast errors in equation (30) obtained from a VAR model of each IDA country over the period between 1990 and 2010. Then, assuming that the MDBs will maintain the same expected grant element, and thus will not ask for a premium on indexed loans, we compute the optimal shares of: foreign currency loans indexed to real GDP, $\gamma^{*}$; foreign currency loans indexed to the dollar value of exports, $x^{*}$, and; inflation-indexed loans denominated in local currency, $h^{*}$.

The optimal shares of the three types of indexed loans are reported in tables 3 and 4, for the 5-year and 10-year horizons, respectively, for the sample of the 40 IDA countries for which data on exports are available to estimate the VAR ${ }^{16}$ Each table shows the debt-to-GDP ratio in column 2, the risk of debt distress in column 3 (low, moderate, high, in distress), the ratio of the variance of exports to the variance of GDP in column 4, the ratio of the variance of real exchange rate depreciation to the variance of GDP in column 5, the optimal share of GDP-indexed loans in column 6, the optimal share of loans indexed to the value of exports in column 7 , and the optimal share of inflation-indexed loans in local currency in column 8 .

Tables 3 and 4 clearly show that GDP growth is not the main source of uncertainty affecting the debt ratio in IDA countries. In fact, the variances of the real exchange-rate and export growth (in dollars) exceed by many times that of accumulated GDP growth. While the specification of our VAR may be too simple to forecast the former variables at long horizons, it is well known that predicting the exchange rate is a difficult task, as it comes close to a random walk.

Despite the relatively low volatility of GDP growth, GDP-indexed loans would be a valuable hedge for many IDA countries. Indeed, the optimal share of such loans, $\gamma^{*}$, is positive in 29 out of 40 countries (at both time horizons) and larger than one in 25 cases at the 5-year horizon and in 28 cases at the 10-year horizon.

\footnotetext{
15 The optimal number of lags for both the endogenous and exogenous variables has been determined by minimizing the Bayesian Information Criterion (BIC).

16 Table 2 shows that data on exports are not available (or sufficient) to estimate a VAR for 25 IDA countries.
} 
Table 3

OPTIMAL SHARES OF INDEXED DEBT - 5-YEAR HORIZON

\begin{tabular}{|c|c|c|c|c|c|c|c|}
\hline & \multirow[b]{2}{*}{ Debt ratio } & \multirow[b]{2}{*}{ Risk } & \multicolumn{2}{|c|}{ Relative variances } & \multicolumn{3}{|c|}{ Optimal shares } \\
\hline & & & $V(x) / V(g)$ & $V(e-p) / V(g)$ & $\gamma^{*}$ & $x^{*}$ & $h^{*}$ \\
\hline Angola & 22 & & 21.7 & 6.6 & 9.0 & 2.0 & 3.6 \\
\hline Bangladesh & 25 & L & 228.9 & 33.4 & 4.4 & 0.2 & 0.9 \\
\hline Benin & 18 & L & 249.1 & 339.3 & -6.7 & 0.5 & 0.6 \\
\hline Burundi & 33 & $\mathrm{H}$ & 82.7 & 12.0 & -1.2 & 0.2 & 1.0 \\
\hline Cambodia & 42 & M & 3.7 & 3.5 & 3.3 & 1.5 & 1.7 \\
\hline Cameroon & 13 & L & 156.2 & 206.4 & 6.4 & 0.6 & 1.0 \\
\hline Congo (the) & 32 & L & 35.5 & 58.9 & 10.0 & 1.7 & 1.3 \\
\hline Côte d'Ivoire & 50 & $\mathrm{D}$ & 11.5 & 14.2 & 0.7 & 0.8 & 0.7 \\
\hline Djibouti & 72 & $\mathrm{H}$ & 22.6 & 0.7 & -0.7 & -0.1 & -1.6 \\
\hline Ethiopia & 24 & L & 11.4 & 30.8 & 1.3 & 0.6 & 0.4 \\
\hline Ghana & 27 & M & 3.3 & 118.4 & 15.5 & 5.3 & 1.5 \\
\hline Guinea & 65 & $\mathrm{D}$ & 117.1 & 34.2 & 0.3 & 0.2 & 0.9 \\
\hline Guyana & 61 & M & 2.7 & 15.3 & 5.6 & 3.1 & 1.3 \\
\hline Haiti & 7 & $\mathrm{H}$ & 198.2 & 186.4 & 50.6 & 4.4 & 5.5 \\
\hline Honduras & 27 & L & 6.5 & 3.1 & -1.6 & 0.4 & 1.7 \\
\hline Kenya & 27 & L & 182.1 & 149.9 & 0.9 & -1.4 & 1.6 \\
\hline Kyrgyzstan & 86 & M & 13.8 & 7.2 & 4.1 & 1.0 & 1.6 \\
\hline Lao People's Democratic Republic & 76 & $\mathrm{H}$ & 238.4 & 163.6 & 10.3 & 0.6 & 0.9 \\
\hline Lesotho & 34 & M & 3.6 & 1.4 & -0.2 & 0.4 & 2.0 \\
\hline Madagascar & 26 & L & 5.4 & 7.0 & -0.1 & 0.0 & 1.1 \\
\hline Malawi & 18 & M & 5.6 & 18.1 & 5.6 & 0.5 & -0.2 \\
\hline Maldives & 64 & $\mathrm{H}$ & 6.1 & 0.6 & 3.0 & 1.3 & 1.7 \\
\hline Mali & 25 & M & 30.3 & 22.6 & 6.3 & 1.0 & 1.5 \\
\hline Mongolia & 39 & L & 24.1 & 8.8 & 6.5 & 1.7 & 1.5 \\
\hline Mozambique & 43 & L & 40.1 & 35.6 & -3.6 & -0.4 & 1.4 \\
\hline Nepal & 29 & M & 51.0 & 12.7 & 3.5 & 0.5 & 0.5 \\
\hline Nicaragua & 73 & M & 28.0 & 121.1 & 2.5 & 1.5 & 1.2 \\
\hline Niger (the) & 20 & M & 71.1 & 50.0 & 5.8 & 0.8 & 0.9 \\
\hline Nigeria & 4 & L & 69.4 & 35.0 & 28.6 & 5.9 & 7.5 \\
\hline Republic of Moldova & 79 & L & 11.9 & 3.3 & 2.1 & 0.6 & 1.2 \\
\hline Rwanda & 14 & M & 2.8 & 0.6 & 5.7 & 2.6 & 4.8 \\
\hline Senegal & 28 & L & 28.7 & 90.2 & 7.7 & 1.2 & 0.8 \\
\hline Sierra Leone & 41 & M & 18.9 & 0.9 & 0.7 & 0.1 & 1.3 \\
\hline Solomon Islands & 32 & M & 16.2 & 1.1 & 2.8 & 0.5 & -0.1 \\
\hline Sudan & 35 & $\mathrm{D}$ & 125.7 & 56.5 & -1.4 & 0.7 & 1.0 \\
\hline Togo & 55 & M & 9.7 & 12.0 & -0.3 & 0.9 & 1.0 \\
\hline Uganda & 18 & L & 39.6 & 13.2 & 3.1 & 0.6 & 1.5 \\
\hline United Republic of Tanzania & 38 & L & 194.2 & 75.1 & 4.7 & 0.0 & 0.8 \\
\hline Vanuatu & 21 & L & 8.3 & 10.9 & -4.1 & -1.1 & -2.4 \\
\hline Yemen & 24 & $\mathrm{H}$ & 58.1 & 110.8 & -0.5 & 1.3 & 0.6 \\
\hline
\end{tabular}


Table 4

OPTIMAL SHARES OF INDEXED DEBT - 10-YEAR HORIZON

\begin{tabular}{|c|c|c|c|c|c|c|c|}
\hline & \multirow[b]{2}{*}{ Debt ratio } & \multirow[b]{2}{*}{ Risk } & \multicolumn{2}{|c|}{ Relative variances } & \multicolumn{3}{|c|}{ Optimal shares } \\
\hline & & & $V(x) N(g)$ & $V(e-p) / V(g)$ & $\gamma^{*}$ & $x^{*}$ & $h^{*}$ \\
\hline Angola & 22 & & 12.4 & 3.1 & 5.0 & 1.6 & 3.2 \\
\hline Bangladesh & 25 & L & 138.1 & 17.9 & 2.8 & 0.2 & 0.9 \\
\hline Benin & 18 & L & 55.4 & 16.4 & 1.8 & -0.8 & 1.4 \\
\hline Burundi & 33 & $\mathrm{H}$ & 14.7 & 3.7 & -2.8 & 0.2 & 1.5 \\
\hline Cambodia & 42 & $M$ & 2.6 & 3.0 & 3.3 & 2.1 & 1.9 \\
\hline Cameroon & 13 & L & 123.0 & 226.2 & 8.9 & 0.2 & 0.9 \\
\hline Congo (the) & 32 & L & 35.9 & 59.1 & 5.8 & 1.0 & 0.7 \\
\hline Côte d'Ivoire & 50 & $\mathrm{D}$ & 4.3 & 9.2 & -0.5 & 0.8 & 0.5 \\
\hline Djibouti & 72 & $\mathrm{H}$ & 14.1 & 0.6 & -0.7 & -0.3 & -1.5 \\
\hline Ethiopia & 24 & L & 10.0 & 134.8 & 1.5 & 0.6 & 0.3 \\
\hline Ghana & 27 & $M$ & 0.0 & 100.8 & 14.2 & 78.5 & 1.4 \\
\hline Guinea & 65 & $\mathrm{D}$ & 1826.8 & 1293.3 & 12.0 & 0.7 & 0.9 \\
\hline Guyana & 61 & M & 2.0 & 13.3 & 5.0 & 3.6 & 1.0 \\
\hline Haiti & 7 & $\mathrm{H}$ & 191.8 & 203.8 & 82.2 & 5.9 & 5.8 \\
\hline Honduras & 27 & $\mathrm{~L}$ & 3.3 & 1.7 & -2.3 & 1.4 & 2.2 \\
\hline Kenya & 27 & $\mathrm{~L}$ & 132.9 & 201.3 & -12.3 & -2.2 & 2.1 \\
\hline Kyrgyzstan & 86 & M & 13.8 & 7.2 & 4.1 & 1.0 & 1.6 \\
\hline Lao People's Democratic Republic & 76 & $\mathrm{H}$ & 234.6 & 315.4 & 8.7 & 0.5 & 0.9 \\
\hline Lesotho & 34 & M & 2.1 & 1.8 & 1.4 & 0.9 & 4.8 \\
\hline Madagascar & 26 & L & 5.5 & 7.5 & -0.2 & -0.1 & 1.2 \\
\hline Malawi & 18 & M & 4.6 & 17.8 & 5.3 & 0.1 & -0.3 \\
\hline Maldives & 64 & $\mathrm{H}$ & 6.1 & 0.6 & 3.0 & 1.3 & 1.7 \\
\hline Mali & 25 & M & 68.3 & 24.9 & 0.9 & 0.8 & 1.6 \\
\hline Mongolia & 39 & L & 20.0 & 21.7 & -0.6 & 2.6 & -3.9 \\
\hline Mozambique & 43 & L & 40.9 & 38.0 & -1.3 & -0.2 & 1.5 \\
\hline Nepal & 29 & M & 68.4 & 14.3 & 4.7 & 0.6 & 0.6 \\
\hline Nicaragua & 73 & M & 24.2 & 70.7 & 2.6 & 0.9 & 1.2 \\
\hline Niger (the) & 20 & M & 136.4 & 86.5 & 7.0 & 0.6 & 0.8 \\
\hline Nigeria & 4 & L & 45.5 & 22.3 & 33.0 & 5.6 & 7.6 \\
\hline Republic of Moldova & 79 & L & 13.3 & 3.6 & 2.2 & 0.6 & 1.2 \\
\hline Rwanda & 14 & M & 3.4 & 0.7 & 5.6 & 2.4 & 5.0 \\
\hline Senegal & 28 & L & 32.6 & 97.0 & 7.3 & 1.1 & 0.8 \\
\hline Sierra Leone & 41 & M & 15.9 & 0.6 & 1.1 & 0.2 & 1.3 \\
\hline Solomon Islands & 32 & M & 12.1 & 0.9 & 2.7 & 0.6 & 0.8 \\
\hline Sudan & 35 & $\mathrm{D}$ & 104.2 & 65.3 & -1.7 & 0.3 & 0.2 \\
\hline Togo & 55 & M & 0.9 & 1.2 & 1.3 & 1.2 & 0.9 \\
\hline Uganda & 18 & L & 31.6 & 9.2 & 4.1 & 0.4 & 1.3 \\
\hline United Republic of Tanzania & 38 & L & 328.3 & 52.0 & 8.5 & 0.1 & 0.5 \\
\hline Vanuatu & 21 & L & 9.2 & 26.3 & -13.2 & -4.3 & -2.8 \\
\hline Yemen & 24 & $\mathrm{H}$ & 37.7 & 97.2 & -2.9 & 0.5 & 0.2 \\
\hline
\end{tabular}


This evidence suggests that in the latter countries GDP indexation does not only help to stabilize the debt ratio, but provides additional insurance. The reason is that GDP growth is unexpectedly low when the real exchange rate depreciates and thus when capital losses realize on foreign currency debt. In fact, if the risk premium is zero (as we assume), equation (14) shows that the optimal share of GDP-indexed loans is greater than one if GDP growth either displays a negative covariance with exchange-rate depreciation or a positive covariance with net exports. A closer look at the estimated covariances (not reported in the tables) clearly points to the relation between output growth and the exchange rate as the main reason for the additional insurance that GDP-indexed loans may offer. This evidence is consistent with economic theory. Productivity shocks may lead to higher economic growth and unexpected real appreciation because of the Balassa-Samuelson effect. Furthermore, sudden stops and capital outflows may lead to output contractions and large depreciations of the exchange rate. Our model captures such effects well and suggests that GDP-indexed loans can also provide some insurance against debt valuation effects in bad times. This evidence points to further benefits of indexation that have not yet been considered in the literature.

However, contrary to what is commonly held, GDP-indexed loans are not always the best insurance instrument. For one fourth of the countries in our sample, the optimal share of GDP-indexed loans is negative which simply means that multilateral loans should not be indexed to GDP. The reason for this result is the finding, in 8 out of 11 countries, of a significant negative covariance of net exports with GDP growth. As unexpectedly high growth may lead to a greater absorption of foreign goods, higher payments on indexed loans could worsen instead of dampening the accumulation of external debt. However, before concluding against GDP indexation, it has to be seen whether an increase in debt payments during expansions might induce a greater control of aggregate demand in these countries. Finally, and interestingly, the case for GDP-indexed loans appears to be unrelated to the risk of debt distress, since countries are equally distributed in all risk categories.

We find that the introduction of foreign currency loans indexed to the dollar value of exports is a valid alternative to GDP-indexation. Tables 3 and 4 show that export-indexed loans would help to stabilize the debt ratio in a large number of IDA countries. Indexing at least a fraction of the debt to the value of exports would provide valuable insurance to 34 IDA countries at both 5- and 10-year horizons. However, full indexation would be optimal only in 16 of these countries, since the others display an optimal share of export-indexed loans below one. The reason is that export-indexed loans provide a hedge against output fluctuations only to the extent that exports are correlated with GDP growth. Although this is generally the case, such a correlation is far from perfect, as shown by the estimated covariances (not reported here).

The results in tables 3 and 4 are consistent with a positive relation between export and GDP growth, either from productivity improvements, export diversification or, more simply, from foreign demand. Interestingly, we find that export indexation, when optimal, also provides a hedge against the valuation losses on foreign currency debt due to real exchange-rate depreciation. Though consistent with the effects of long run productivity improvements, this result more likely reflects the impact of terms-of-trade shocks on the value of exports and the real exchange rate. It suggests that export-indexed loans could provide a valuable alternative to commodity price indexation, especially to those countries that do not depend on a single commodity export.

There is however evidence for the 5-year scenario that 6 countries would not benefit from export-indexed loans and that this group enlarges to 8 in the 10 -year scenario. In the latter case, there are other 8 countries for which indexation should cover less than half of their debts. Although in a few cases this result is explained by a positive covariance between export growth and the exchange rate depreciation, ${ }^{17}$ a low or negative share of indexed loans is mainly due to a significant negative covariance of the growth of export with the ratio of net exports to GDP. This evidence is somewhat surprising but a rationale can be

\footnotetext{
17 The countries are Benin, Kenya, Madagascar, Malawi, and Mozambique.
} 
found in a positive relation characterizing the dynamics of exports, GDP and demand for foreign goods. If anything, this evidence suggests that, as for GDP indexation, export-indexed loans do not offer a 'one size fits all solution' to the problem of stabilizing the debt ratio. Finally, it is worth noting that in 5 countries conventional loans are preferable to both GDP and export indexation.

The last innovation that we consider is the denomination of loans in the borrower's currency coupled with an inflation link. This debt instrument provides full protection against real exchange-rate depreciation and appears to be useful in stabilizing the debt ratio in a large number of countries. As shown in the last columns of tables 3 and 4, 36 out of 40 countries would benefit from having at least a fraction of their debts denominated in local currency and indexed to inflation. The optimal share of such debt is equal or greater than 0.9 in 29 countries at the 5-year horizon and in 26 countries at the 10 -year horizon. As noted earlier, the covariance between exchange-rate depreciation and GDP growth is negative. This implies an additional insurance role for domestic currency loans; they avoid the capital losses on conventional loans when this is most valuable, i.e. when output growth is lower than expected. Indeed, real exchange-rate depreciations due to productivity shocks and capital outflows are a major cause of debt vulnerability which calls for either indexing the debt to GDP or denominating it in local currency. On the other hand, domestic currency loans are not as good a hedge as conventional loans against shocks to net exports. We find that in about half of our sample the ratio of net exports to GDP is positively correlated to exchange-rate depreciation which explains why, in most cases, the optimal share of inflation-indexed loans denominated in domestic currency is close to one.

In countries where net exports are particularly sensitive to exchange rate depreciation, domestic currency loans provide no insurance benefits, since exposure to currency risk allows to hedge shocks to net exports. The optimal share of domestic currency debt is negative in five countries, either at the 5-year or 10-year horizon: Djibouti, Malawi, Mongolia, Solomon Islands and Vanuatu. Interestingly, conventional loans are the best debt instrument in the cases of Djibouti and Vanuatu where no indexation scheme appears to improve debt sustainability.

The results of our analysis provide strong evidence in favour of domestic currency loans indexed to inflation. Lending in the borrower's currency helps to stabilize the debt ratio against unexpected movements in the real exchange rate which is the main cause of debt vulnerability. Such innovation also seems easier to implement because inflation indexation has been widely experimented and inflation is released with fewer lags and less revisions than either data on GDP or exports. On the other hand, because in low income countries the real exchange rate tends to appreciate in the long run, domestic currency denomination may increase the expected cost of debt service, a problem that we have sidestepped assuming a zero risk premium. This raises the issue of how MDBs can maintain the concessionality of their loans while lending in local currencies. The incentive for opportunistic devaluations created by domestic currency debt is also a concern that inflation indexation might not fully eliminate.

We also find supportive evidence for GDP-indexed or export-indexed loans, but though such instruments provide valuable insurance to the majority of IDA countries in our sample, they benefit a fewer number of countries than domestic currency loans. A main lesson from our analysis is that a 'one size fits all solution' does not exist to the problem of stabilizing the debt ratio. This result is unfortunate in that it poses a serious obstacle for a general approach to the management of IDA countries' debt. 


\section{AN EMPIRICAL ASSESSMENT OF THE COST OF PROVIDING INSURANCE}

Although multilateral lenders, by indexing their loans to the LICs' ability to pay, may gain from a lower frequency of debt crises, providing such insurance is risky as the volatility of debt payments increase. To implement an indexation programme with little or no insurance premium, GDP, export or currency risk must be uncorrelated across LICs, so that a diversified portfolio of loans can limit the risk exposure of multilateral lenders.

In this section we study the risk-return characteristics of a portfolio of indexed loans to the same group of 40 IDA countries considered in the previous section, to assess the potential for risk diversification and thus the feasibility of an indexation programme.

First, we shall examine risk diversification by studying the risk characteristics of a MDBs' portfolio of loans indexed to real GDP or to the value of exports, or denominated in domestic currency. Second, since the volatility measures proposed in the literature are derived from within-sample estimates of expected returns, we shall provide evidence on unexpected 10-year portfolio returns to evaluate the risk arising from prediction errors. Finally, we shall estimate the beta coefficients from a capital asset pricing model using the correlations of VAR forecast errors between the returns on indexed loans and the GDP of OECD countries.

\section{A. Risk diversification: the volatility of a portfolio of indexed loans}

We first analyse the volatility of the returns on a portfolio of indexed loans to IDA countries over the period 2000-2010, where the country weights in the portfolio are equal to their fraction of multilateral debt at the end of 1999. We investigate whether this portfolio would be significantly less volatile than the individual countries' loans, as it would be the case if GDP (or export or currency depreciation) were uncorrelated across countries; i.e. we examine whether risk could be reduced through portfolio diversification.

We follow a similar approach to that proposed by Hausmann and Rigobon (2003). First, for each country in our sample we measure the volatility of the return on an indexed-loan as the standard error of the following regression:

$$
\ln \left(Y_{t}\right)=\mu+\ln \left(Y_{t-1}\right)+\varepsilon_{t}
$$

where the variable $Y_{t}$ to which loan payments are indexed (or depend) is modelled as a random walk with drift. $Y_{t}$ is alternatively: (i) the real value of GDP in local currency; (ii) the dollar value of exports; and (iii) the real exchange rate (for a given United States price level); i.e. the dollar value of an inflation-indexed domestic-currency loan. There are two motivations for this approach. First, for most IDA countries in our sample, a random walk with drift is a good description of the stochastic processes followed by the three variables under consideration; this null hypothesis is rejected in formal ADF tests only in 5 out of 120 cases of which 3 are for GDP, and 1 each for the value of exports and the real exchange rate. ${ }^{18}$ Second, the estimated drift $\hat{\mu}$, i.e. the mean growth rate over the sample period, has the natural interpretation of the ex-post baseline growth rate of either GDP, exports or the real exchange rate. Hence, if the baseline growth were correctly predicted at the time the loans were disbursed, the regression residuals, $\hat{\varepsilon}_{t}$, would provide an estimate of the annual holding returns on GDP-indexed and export-indexed loans. This would also be the case for domestic currency loans (despite the absence of a contractually defined

\footnotetext{
18 The results of ADF tests are available by the authors upon request.
} 
baseline real exchange rate) under the reasonable assumption that IDA countries would have to be compensated for the expected real appreciation of their exchange rates.

Then, we compute the volatility of the MDBs' portfolio as follows. Consistently with our proposal for the indexation method, we construct the series of the annual return on such portfolio taking for each year, $t$, the weighted average of the residuals, $\hat{\varepsilon}_{i t}$, from the 40 country regressions. The weights of the portfolio are calculated as the outstanding multilateral debt of each country divided by the total multilateral debt of these countries in 1999. Finally, we compute the volatility of the portfolio return as the square root of the average of the squared elements of the resulting series, i.e. the statistical counterpart of the standard errors of the individual country regressions. Hence, we depart from Hausmann and Rigobon (2003) who use the portfolio weights to first compute the basket real exchange rate (the portfolio of IDA countries' real exchange rates) and then the standard error of the real exchangerate depreciation of the basket currency. However, we also report this volatility measure to compare our results to those of Hausmann and Rigobon.

Our results are reported in figure 1, for GDPindexed, export-indexed, and domestic-currency inflation-indexed loans, from the top to the bottom panel. The continuous black line in figure 1 displays, in increasing order, the standard errors of the growth rates of GDP, exports and the real exchange rate obtained from the singlecountry regressions, i.e. our measure of the annual return volatility of the indexed loans to the 40 IDA countries. The average standard error in the sample is indicated by the horizontal dashed light line, while the horizontal continuous line reports the standard error of the annual return on the MDBs' portfolio and the dashed dark line the corresponding Hausmann and Rigobon's measure of the portfolio volatility.

The visual impression conveyed by figure 1 is that there is a tremendous amount of risk diversification by lending to IDA countries whatever is the type of indexation. Indeed, the volatility of the MDBs' portfolio is not only significantly lower than the sample average of the volatilities of the 40 IDA loans, but very few countries display a return volatility lower than
Figure 1

RISK DIVERSIFICATION OPPORTUNITIES

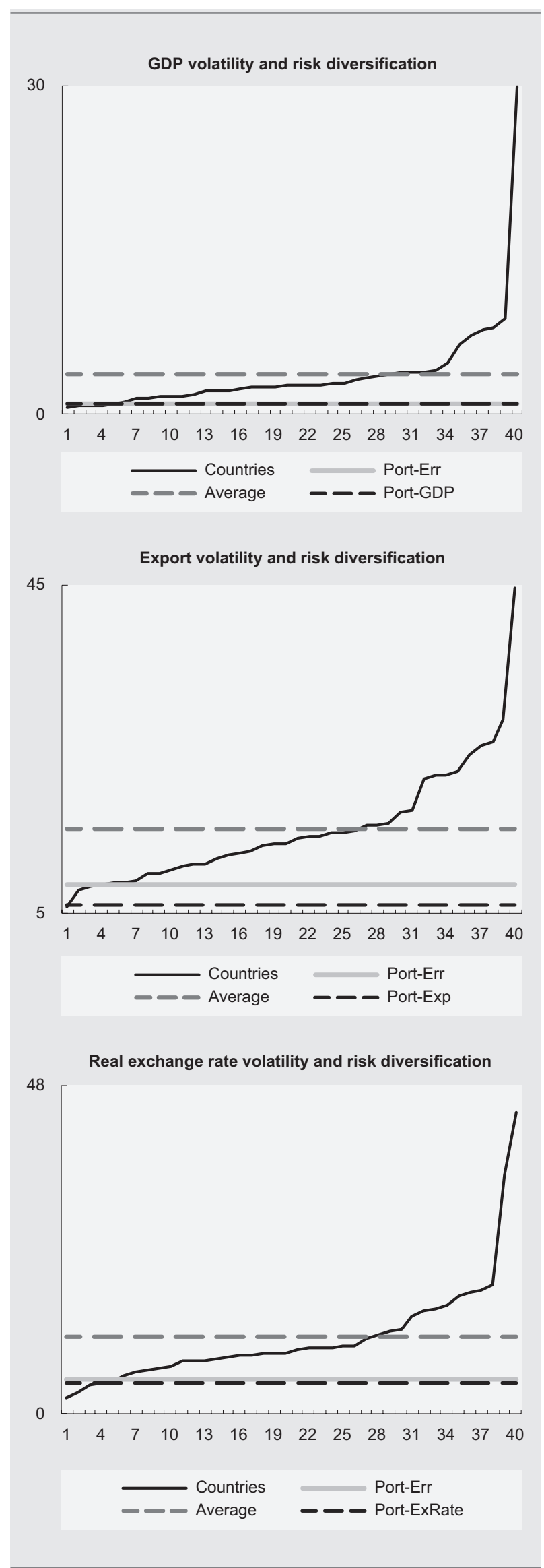


Table 5

RISK DIVERSIFICATION PORTFOLIO VOLATILITIES

\begin{tabular}{lcccc}
\hline & $\begin{array}{c}\text { Portfolio } \\
\text { volatility }\end{array}$ & \multicolumn{3}{c}{ Individual loan volatility } \\
\cline { 3 - 6 } & & $\begin{array}{c}\text { Sample } \\
\text { average }\end{array}$ & $\begin{array}{c}\text { Mini- } \\
\text { mum }\end{array}$ & $\begin{array}{c}\text { Maxi- } \\
\text { mum }\end{array}$ \\
\hline GDP-indexed loans & 1.1 & 3.8 & 0.6 & 29.9 \\
Export-indexed loans & 8.5 & 15.4 & 6.0 & 44.8 \\
Domestic currency loans & 5.5 & 11.8 & 2.5 & 45.9 \\
\hline
\end{tabular}

the MDBs' portfolio; just 5, 3 and 5 in the case of GDP-indexed, export-indexed and domesticcurrency loans, respectively.

The first row of table 5 shows that the average standard error of the return on a GDP-indexed loan (the standard error of GDP growth) is $3.8 \mathrm{per}$ cent, with a maximum of 29.9 per cent and a minimum of 0.6 per cent, while the standard error of the annual return on the MDBs' portfolio is only 1.1 per cent. Hence, the risk of an overall portfolio of GDP-indexed loans is less than one third of the average volatility of the individual loans. The opportunities for risk diversification are slightly smaller in the case of export-indexed loans. As reported in the second row, the annual return volatility on a portfolio of such loans is 8.5 per cent, about one half the average standard error of the growth rate of exports (15.4 per cent) with individual-country loans ranging from a minimum volatility of 6.0 to maximum of 44.8 per cent. The last row of table 5 considers the volatility of the dollar return on domestic currency loans indexed to inflation (the standard error of real exchange rate depreciations). While, the average standard error in the sample is 11.8 per cent, with a maximum of 45.9 per cent and a minimum of 2.5 per cent, the standard error of the annual return on the MDBs' portfolio is only 5.5 per cent, less than one half of the sample average. ${ }^{19}$

All in all, it appears that the individual country risk of indexed lending can be easily diversified in the MDBs' portfolio. The potential for risk diversification is strongest in the case of GDP-indexed loans. The degree of diversification appears substantial even for the portfolio of export-indexed loans that has the worst performance. However, this evidence is far from being conclusive because looking at the volatility of annual returns might not be informative to ascertain the return-risk of long maturity loans such as those extended by the IDA window of the World Bank. In fact, under the maintained hypothesis of random-walk processes, the cumulated return over the sample period (relative to baseline growth) would be estimated by the sum of the regression residuals, $\hat{\varepsilon}_{t}$, which is equal to zero by construction. The reason is that this approach implicitly assumes that the baseline growth of the indexing variables is equal to the estimated drift, $\hat{\mu}$, that is, that the baseline growth is correctly predicted at the time the loans are disbursed. In the next section, we provide evidence on the variability of 10-year returns on indexed loans arising from prediction errors.

\section{B. Unexpected 10-year return on indexed loans}

If the long-run growth rate of GDP or exports or the depreciation of the real exchange rate were perfectly foreseen, indexed loans would still provide a hedge against cyclical or exchange-rate fluctuations but they would offer little protection against a permanent fall in LICs' ability to pay. Similarly, the returns on indexed loans over a long horizon, relative to conventional loans, would also be close to zero as, say, GDP would approach its baseline level. It is then important to assess the effect of the prediction errors that are inevitably made in estimating the long-run growth rates of the variables to which loans are indexed and thus in setting their baseline growth rates.

In this section, we maintain the hypothesis that GDP, exports and the real exchange rates evolve as random walks with drift but assume that their expected growth rates in 1999, used to set the baseline rates in the

\footnotetext{
19 Hausmann and Rigobon (2003) finds a standard deviation equal to 15.8 per cent for the sample average and of 2.9 per cent for the overall portfolio that suggests more risk diversification, a result possibly explained by their 1980-2000 sample period. In fact,when we construct the portfolio using their method, the volatility of the portfolio decreases only slightly to 4.7 per cent.
} 
loan contracts, are equal to the mean of the two drifts separately estimated for the periods 1990 1999 and 2000-2010. In other words, we assume that expectations are half based on historical values and half based on perfect foresight. Then, we compute the unexpected 10-year return on each individual country's loan as the difference between the log of actual GDP (or export or the real exchange rate) in 2010 and the log of the baseline level of GDP in the same year, where the latter is obtained by cumulating the expected growth rate of GDP previously derived as the drift mean. Finally, we compute the 10 -year returns on the three portfolios of GDP-indexed, exportindexed and domestic currency loans by taking the weighted average of the returns on the individual countries' loans with weights corresponding to the debt shares in 1999.

The 10-year returns (relative to conventional loans) are displayed in figure 2 for GDP-indexed, export-indexed, and domestic-currency inflationindexed loans, from the top to the bottom panel. The continuous black line displays, in increasing order, the returns on the individual loans to the 40 IDA countries. The horizontal light line reports the 10-year return on the MDBs' portfolio, while the horizontal dashed line indicates the sample average of the individual loan returns.

The return on the MDBs' portfolio is lower than the average of the returns on the individual country loans and is positive for all three types of indexation considered. This reflects the improved performance of IDA countries over the last ten years relative to the previous decade; on average, GDP and exports grew faster and the real exchange rate appreciated at a faster rate.

More importantly, the cumulated returns on the MDBs' portfolios of the three types of loans provide interesting evidence on the potential gains or losses that could result from loan indexation, while the returns on individual loans are suggestive of the insurance that countries could obtain. Table 6 shows, in the first row, that the 10-year return on the portfolio of GDPindexed loans is 7.1 per cent, while the returns on individual loans vary from a minimum of -17.4 per cent to a maximum of 76.9 per cent. The 10 -year return on the portfolio of export-indexed loans, reported in the second row, is as high as 44.0 per cent while the range of individual loan returns
Figure 2

\section{UNEXPECTED 10-YEAR RETURN}
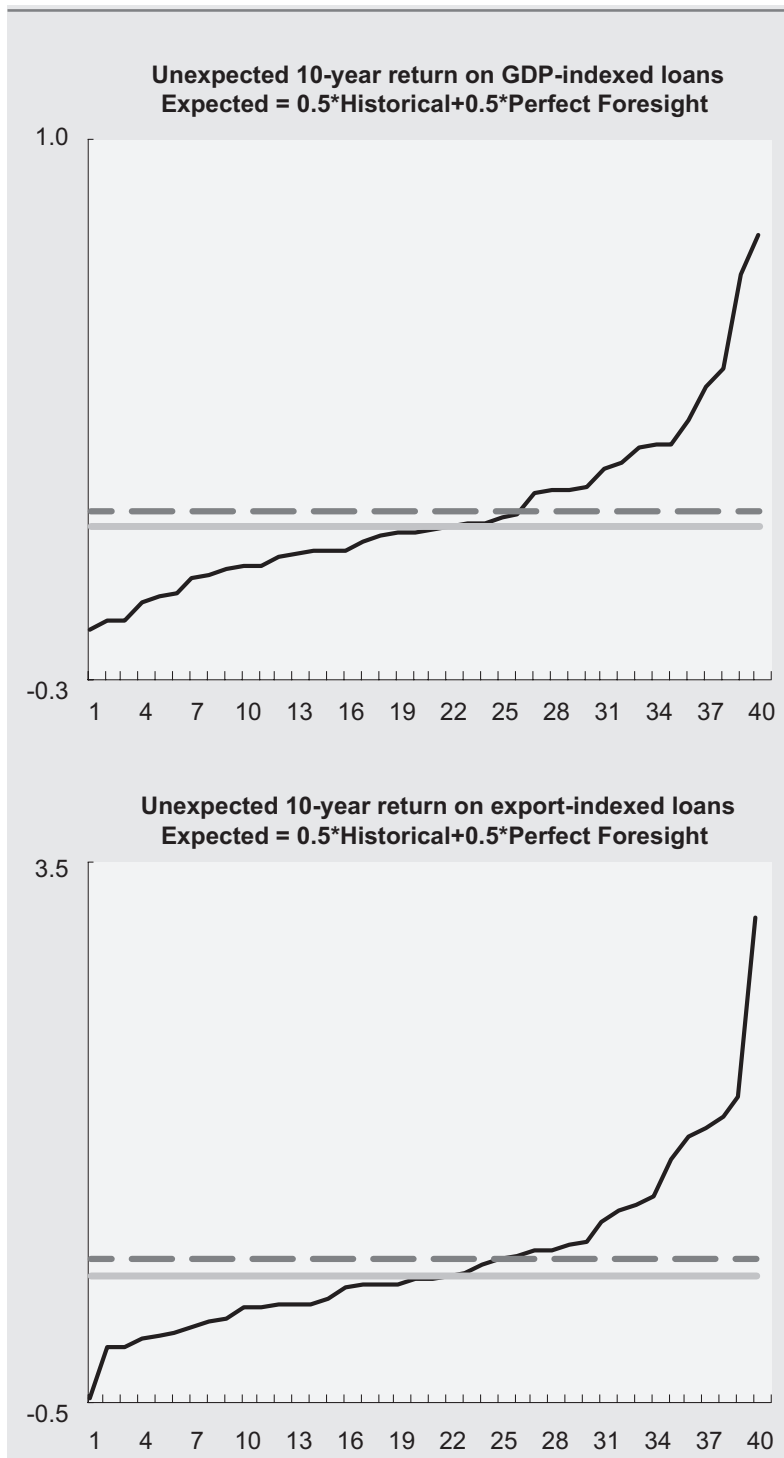

Unexpected 10-year return on domestic currency loans Expected $=0.5^{\star}$ Historical $+0.5^{\star}$ Perfect Foresight

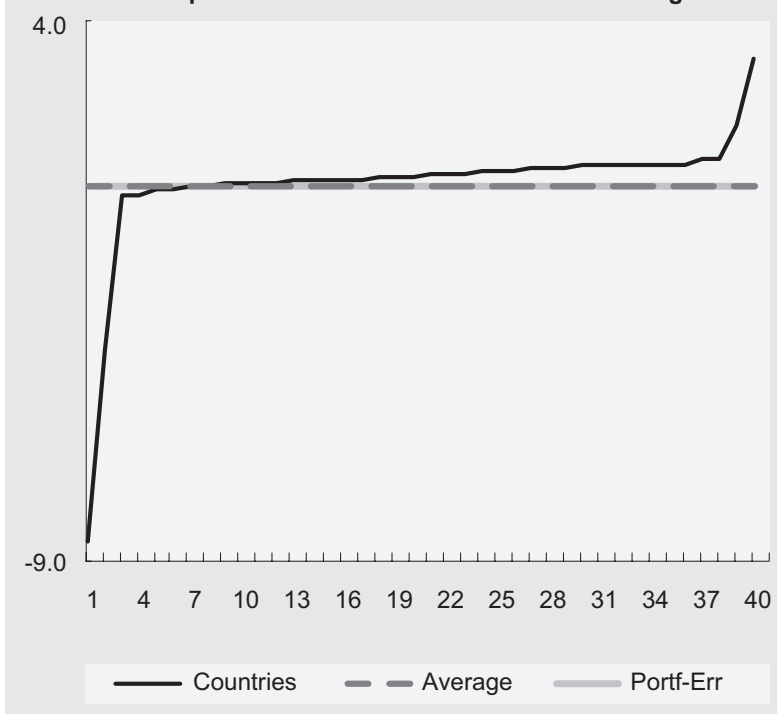


Table 6

PORTFOLIO RETURNS OVER

THE PERIOD 2000-2010

\begin{tabular}{lrrrr}
\hline & $\begin{array}{c}\text { Portfolio } \\
\text { returns }\end{array}$ & \multicolumn{3}{c}{ Individual loan volatility } \\
\cline { 3 - 5 } & & $\begin{array}{c}\text { Sample } \\
\text { average }\end{array}$ & $\begin{array}{c}\text { Mini- } \\
\text { mum }\end{array}$ & $\begin{array}{c}\text { Maxi- } \\
\text { mum }\end{array}$ \\
\hline GDP-indexed loans & 7.1 & 10.7 & -17.4 & 76.9 \\
Export-indexed loans & 44.0 & 57.9 & -45.9 & 308.1 \\
Domestic currency loans & 1.3 & 7.2 & -852.8 & 309.4 \\
\hline
\end{tabular}

is sizeable; it goes from -45.9 per cent to an astonishing 308.1 per cent. The 10-year (dollar) return on the portfolio of inflation-indexed loans denominated in domestic currencies is 1.3 per cent. Although the variation of returns on individual loans is huge, from -852.8 to 309.4 per cent, 34 countries stay within a narrower range from -14.7 to 69.4 per cent.

This evidence suggests that indexing loans to the value of exports would be extremely risky for multilateral lenders because predicting the growth rate of exports is an almost impossible

task. By contrast, the strategies of indexing loans to GDP or lending in the borrower's domestic currency appear more feasible. It is however clear that large unexpected real depreciations would wipe out the dollar value of domestic currency debt while large unexpected real appreciations would dramatically increase its burden relative to conventional debt. As a result, it is hard to think that domestic currency lending would not affect the monetary policy of the borrowing countries.

\section{A capital asset pricing model of indexed loans}

The capital asset pricing model is often used in the literature (see e.g. Borensztein and Mauro, 2004) as a starting point to evaluate how markets would price GDP-indexed bonds, in particular, how large would be the insurance premium that investors require to hold such bonds. The CAPM implies that such premium depends only on the systematic component of GDP risk that is captured by the conditional correlation of the bond return with the return on the market portfolio; i.e. on the beta coefficient. According to the CAPM the expected return on any asset must be equal to

$$
E_{t} R_{i, t+1}=R_{F, t+1}+\left[E_{t} R_{M, t+1}-R_{F, t+1}\right] \frac{\operatorname{Cov}_{t}\left(R_{i, t+1} ; R_{M, t+1}\right)}{\operatorname{Var}_{t}\left(R_{M, t+1}\right)}
$$

where $R_{F, t}$ is the risk-free rate, $R_{M, t}$ is the return on the market portfolio and where the ratio of the covariance of the asset return with the market return to the variance of the latter is the beta coefficient.

Although the multilateral loans received by LICs are not traded in a market, and multilateral lenders barely hold any other financial asset, the beta coefficients might convey information on whether the risk of indexed-loans can be diversified away. We must however decide what would be a meaningful 'marketportfolio return' that could be used for this purpose. Since multilateral lenders, such as the IDA window of the World Bank, are mainly funded through the contributions provided by their wealthier member States, GDP growth of OECD countries is a reasonable candidate for the market-portfolio return. The higher the correlation of LICs' GDP growth (or export growth or real exchange-rate appreciations) with GDP growth in OECD countries - i.e. the higher the beta coefficients - the greater the risk that loan repayments may fall at times when fiscal resources for MDBs' funding are scarce.

Defining with $Y_{t}$ the variable to which loan payments are indexed, and abstracting from valuation effects (i.e. capital gains or losses) which arise, for example, if $Y_{t}$ is autocorrelated, the return on an indexed loan can be approximated by $R+y_{t}-y_{t}^{*}$ where $R$ is the fixed rate component of the return, $y_{t}$ is the log of $Y_{t}$ and $y_{t}^{*}$ is the log of its baseline level. Then, denoting with $q_{t}$ the log of GDP in OECD countries, the beta coefficient is equal to 


$$
\beta_{C A P M}=\frac{\operatorname{Cov}_{t}\left[\left(R+y_{t+1}-y_{t+1}^{*}\right) ;\left(q_{t+1}-q_{t}\right)\right]}{\operatorname{Var}_{t}\left[q_{t+1}-q_{t}\right]}=\frac{\operatorname{Cov}_{t}\left[\left(y_{t+1}-y_{t}\right) ;\left(q_{t+1}-q_{t}\right)\right]}{\operatorname{Var}_{t}\left[q_{t+1}-q_{t}\right]}
$$

where we have used the fact that $y_{t+1}^{*}$ and $y_{t}$ are known at time $t$.

Borensztein and Mauro (2004) estimate the beta coefficients through simple regressions of individual countries' GDP growth rates on OECD growth rates. We run the same regressions for IDA countries over the period 1990-2010 and obtained similar results: the beta coefficients are generally low, not significant and even negative for one fourth of our sample. ${ }^{20}$ The beta coefficients estimated by regressing the rate of real exchange appreciation on OECD growth gave similar results. This evidence points to a weak correlation of the returns on loans indexed to GDP or denominated in domestic currency with the fiscal resources of multilateral lenders and suggests that the individual country return-risk on such loans could be easily diversified away. By contrast, we found high and significant beta coefficients for the growth rate of exports; its correlation with OECD growth suggests that export indexation could be risky for multilateral lenders.

However, the use of univariate regressions to estimate conditional correlation coefficients - i.e. the beta coefficients - is correct only if growth rates at time $t+1$ are uncorrelated with other variables in the information set at $t$, as it would be the case if GDP, exports and the exchange rate were pure random walks. A better approach to the estimation of beta coefficients is to use the variances and covariances of the residuals obtained from a VAR analysis. We do so using the variances and covariances of the forecast errors of the VAR model presented in section VII. ${ }^{21}$ This allows us to estimate the beta coefficients for indexed-loan returns over investment horizons longer than one year. This is particularly useful in our case, since multilateral loans have a long time to maturity. Table 7 reports the beta coefficients for the returns on: (i) GDP-indexed loans; (ii) export-indexed loans; and (iii) inflation-indexed loans denominated in domestic currency. They are computed as the covariances of the forecast errors of the log of GDP, exports and the real exchange rate with the log of GDP of OECD countries divided by the variance of the forecast error of the latter variable. While the focus is on the 5-year and 10-year horizons, beta coefficients for the 1-year horizon are also reported in columns 1-3 for a comparison with the results in the literature.

In the case of GDP-indexed loans, beta coefficients are generally low for all countries at all horizon considered. ${ }^{22}$ At the 1-year horizon the unweighted average of the coefficients is only 0.33 (the median is 0.28) which is lower than the average correlation found by Borensztein and Mauro (2004) for a different sample of developing countries. More important, both the average and the median of the coefficients decrease as the time horizon extends to ten years. When we focus on 5-year and 10-year horizons, no more than 13 countries exhibit a GDP correlation with OECD economies greater than 0.5 . These results clearly suggests that GDP growth and thus the payments on indexed loans are, on average, very weakly correlated with OECD growth and thus with the fiscal resources of multilateral lenders. The risk premium implied by the CAPM on GDP-indexed loans is easy to compute using equation (32). ${ }^{23}$ Taking the average growth rate of GDP in the OECD area over the sample period, 4.4 per cent, as the expected return on the market portfolio, and 0.75 per cent as the risk-free interest rate on conventional IDA loans, the risk premium for the median IDA country is as low as $(4.4-0.75)^{*} 0.28$, i.e. just one percentage point per year. And, if we consider a 10 -year horizon, and thus a median beta coefficient of 0.18 , the risk premium

\footnotetext{
${ }^{20}$ Results are available from the authors upon request.

21 The model was slightly modified to add an equation for the GDP of OECD economies that was treated as an exogenous variable in section VII.

22 With the exception of Vanuatu, beta coefficients range from -1.3 to 2.1 .

${ }^{23}$ We assume that baseline GDP growth equal expected GDP growth, so that the expected return on a GDP-indexed loan equals the sum of the risk free rate and the risk premium.
} 
Table 7

BETA COEFFICIENTS OF INDEXED DEBT

\begin{tabular}{|c|c|c|c|c|c|c|c|c|c|}
\hline & \multicolumn{3}{|c|}{ 1-year horizon } & \multicolumn{3}{|c|}{ 5-year horizon } & \multicolumn{3}{|c|}{ 10-year horizon } \\
\hline & $G D P$ & Export & Dom-curr & $G D P$ & Export & Dom-cur & $G D P$ & Export & Dom-curr \\
\hline Angola & 1.3 & 9.3 & 4.5 & 0.3 & 6.7 & 1.5 & 0.4 & 8.5 & 2.9 \\
\hline Bangladesh & 0.2 & 1.1 & -0.9 & 0.3 & 4.2 & -0.2 & 0.3 & 4.0 & -0.4 \\
\hline Benin & 0.6 & -3.7 & -3.6 & 0.6 & -5.4 & -3.9 & 0.2 & -2.8 & -2.0 \\
\hline Burundi & 1.0 & -0.3 & -2.1 & 0.1 & 2.9 & -2.1 & -0.4 & -3.1 & -4.7 \\
\hline Cambodia & 0.9 & 0.4 & 0.2 & 1.5 & 2.2 & -0.2 & 1.6 & 3.1 & -0.7 \\
\hline Cameroon & 0.4 & 6.6 & 2.9 & 0.3 & 2.6 & -0.5 & 0.5 & 2.6 & -0.8 \\
\hline Congo (the) & -1.0 & 9.6 & 14.9 & -1.2 & 5.3 & 6.9 & -1.9 & 0.2 & 0.7 \\
\hline Côte d'Ivoire & -1.2 & -0.5 & -2.5 & -1.4 & -1.3 & 1.6 & 0.5 & -4.5 & -2.7 \\
\hline Djibouti & -0.5 & -3.8 & -0.3 & 0.1 & -2.5 & 0.0 & 0.2 & -1.7 & 0.3 \\
\hline Ethiopia & -1.3 & 3.5 & 3.7 & -0.9 & 2.2 & -1.7 & 0.1 & 7.3 & -1.4 \\
\hline Ghana & 0.2 & 0.7 & 5.1 & -0.2 & 0.0 & -1.7 & 0.1 & 1.3 & -2.6 \\
\hline Guinea & 0.5 & 6.9 & -3.2 & 0.5 & 2.5 & -0.9 & 0.5 & 0.4 & -0.9 \\
\hline Guyana & 1.3 & 3.0 & -0.1 & 0.5 & 1.2 & 1.1 & 0.0 & 0.4 & 3.1 \\
\hline Haiti & -0.1 & 1.8 & 0.2 & 0.2 & 3.6 & -1.6 & 0.2 & 2.8 & -2.7 \\
\hline Honduras & 0.6 & 2.6 & -0.6 & 0.1 & 4.4 & 0.3 & 0.0 & 4.7 & 0.6 \\
\hline Kenya & 0.3 & -3.6 & 1.9 & 0.5 & 4.3 & 0.1 & 0.6 & 11.9 & -1.8 \\
\hline Kyrgyzstan & 0.2 & 4.9 & 1.3 & -0.1 & 0.1 & -0.3 & -0.2 & -0.5 & -0.6 \\
\hline Lao People's Dem. Rep. & 0.3 & 1.0 & 0.7 & -0.2 & -0.4 & -3.5 & -0.2 & 2.8 & -1.4 \\
\hline Lesotho & 0.4 & 1.9 & -2.3 & -0.6 & 4.1 & -1.5 & -0.3 & 6.1 & -1.7 \\
\hline Madagascar & 0.2 & 7.0 & -6.4 & 2.1 & 4.4 & -6.5 & 2.1 & 4.4 & -3.9 \\
\hline Malawi & -0.4 & -5.7 & -2.4 & -1.6 & -6.4 & -1.4 & -1.8 & -6.4 & -1.3 \\
\hline Maldives & 0.3 & -1.7 & -1.8 & 0.7 & 0.3 & -1.0 & 1.6 & 3.1 & -0.9 \\
\hline Mali & -0.3 & -0.4 & -3.2 & 1.2 & 2.8 & 0.0 & 1.5 & 3.2 & -0.5 \\
\hline Mongolia & 1.3 & 7.0 & 4.4 & 0.9 & 6.9 & 2.9 & 0.8 & 8.2 & 3.4 \\
\hline Mozambique & 0.5 & 3.5 & 1.1 & -0.3 & 3.6 & 1.1 & -0.6 & 4.4 & 1.7 \\
\hline Nepal & -0.2 & 2.3 & -0.7 & 0.3 & -0.7 & 0.0 & 0.2 & -3.0 & -0.8 \\
\hline Nicaragua & 1.1 & 0.4 & 1.0 & 0.7 & -0.9 & -1.1 & 0.1 & -3.5 & -1.3 \\
\hline Niger (the) & -0.2 & -2.5 & 0.3 & 0.6 & -2.0 & -0.8 & 1.0 & 0.0 & 0.4 \\
\hline Nigeria & 0.4 & 9.6 & 4.9 & -0.4 & 6.1 & 4.0 & -0.9 & 3.5 & 2.8 \\
\hline Republic of Moldova & 0.9 & -0.6 & -2.6 & 1.2 & 2.7 & -0.2 & 1.1 & 2.3 & 0.1 \\
\hline Rwanda & 0.6 & -4.3 & -2.2 & 1.8 & 0.9 & -1.2 & -1.7 & -12.7 & -11.7 \\
\hline Senegal & 0.6 & 5.5 & 5.5 & 0.4 & 0.3 & 0.9 & 0.3 & -0.3 & 1.5 \\
\hline Sierra Leone & -1.0 & -8.6 & 0.6 & -2.1 & -2.9 & 1.2 & -2.2 & 1.4 & 1.7 \\
\hline Solomon Islands & 1.1 & 0.9 & 0.8 & 0.5 & 0.9 & -0.4 & 1.8 & 9.7 & -0.4 \\
\hline Sudan & 0.3 & 19.5 & 7.7 & -0.3 & 8.3 & 2.3 & -0.1 & 5.7 & -4.0 \\
\hline Togo & 0.5 & -1.6 & -1.9 & -0.8 & 0.4 & -0.6 & -1.5 & 2.7 & 1.0 \\
\hline Uganda & -0.6 & -3.4 & -1.1 & -0.4 & -1.7 & -0.4 & 0.1 & 1.4 & 1.6 \\
\hline United Rep. of Tanzania & 0.1 & -0.4 & 0.3 & 0.1 & 0.5 & -0.1 & 0.0 & 0.7 & -0.6 \\
\hline Vanuatu & 4.2 & 11.7 & 0.2 & 3.1 & 7.6 & -3.4 & 3.5 & 8.6 & -2.5 \\
\hline Yemen & -0.5 & 6.9 & 2.3 & 0.0 & 6.0 & 4.7 & 0.6 & 2.9 & 2.1 \\
\hline Mean & 0.3 & 2.2 & 0.7 & 0.2 & 1.9 & -0.2 & 0.2 & 2.0 & -0.7 \\
\hline Mean no outliers & 0.3 & 1.9 & 0.4 & 0.2 & 1.9 & -0.2 & 0.2 & 2.2 & -0.5 \\
\hline Median & 0.3 & 1.0 & 0.2 & 0.3 & 2.2 & -0.3 & 0.2 & 2.6 & -0.6 \\
\hline N.obs Beta $>0.5$ & 15 & 23 & 17 & 13 & 25 & 11 & 13 & 26 & 12 \\
\hline
\end{tabular}


falls to 0.7 percentage points. Finally, as beta coefficients vary considerably across countries, so do their income growth rates, which suggests, once more, large opportunities for risk diversification.

Turning to export-indexed loans, we find that beta coefficients are positive and large with an unweighted average around 2 at all horizon considered. This finding cannot be attributed to a few outliers, since the beta coefficient for the median IDA country is above 1 at the shorter horizon and increases up to 2.6 at the longer horizon. Indeed, the number of countries with a coefficient greater than 0.5 is as high as 23 at the 1 -year horizon and reaches 26 at the 10-year horizon. Export growth appears, perhaps not surprisingly, to be fairly correlated with OECD growth and thus with the fiscal resources of multilateral lenders. This evidence suggests that export-indexed loans may expose multilateral lenders to the risk of lower reflows at times when their funding needs are highest because of the weak performance of OECD donors. Therefore, the risk-return characteristics of export-indexed loans make such instruments the least appealing from the perspective of minimizing the risk exposure of multilateral lenders.

A different conclusion is reached if we consider inflation-indexed loans denominated in the domestic currencies of IDA borrowers. Table 7 shows that, at the 1-year horizon, the unweighted average of the beta coefficients for the dollar return on such loans is 0.67 despite the high coefficients reported for the Democratic Republic of the Congo and the Sudan, possibly due to imprecisely forecasted real exchange appreciations. In fact, the beta coefficient for the median IDA country is just 0.39 , not much higher than in the case of GDP-indexed loans. Furthermore, at longer horizons, over which the risk exposure of multilateral lenders should be evaluated, the dollar return on domestic currency loans tends to be negatively correlated with OECD growth, as shown by the negative average and median beta coefficients. Since the real exchange rate of IDA countries tends to appreciate when OECD growth is lower than expected, the increase in the dollar value of domestic currency debt may stabilize donors' resources. This is the case for 25 countries in our sample for which the risk premium implied by the CAPM is even negative. More generally, it appears that no premium would be needed on domestic-currency lending to match the expected return on conventional debt, a result which is consistent with the findings of Hausmann and Rigobon (2003).

The evidence provided in this section suggests that the individual country risk of indexed lending could be easily diversified in the MDBs' portfolio. The potential for risk diversification is greater in the case of GDP-indexed loans and local currency loans while the performance of export-indexed loans is weaker. This conclusion holds true whether the volatility of MDBs' portfolios is compared to the risk of individual countries' loans (see section VIII.A) or the CAPM beta correlations with OECD growth are compared across countries. Summing up, there are ample opportunities for risk-sharing among IDA countries, making it feasible for MDBs to provide loans indexed to GDP or to inflation and denominated in local currencies. Such loans could be extended at current interest rates, since the insurance premium implied by CAPM estimation is low while the frequency of debt distress episodes would be reduced.

We also showed evidence of large unexpected 10-year portfolio returns arising from prediction errors of GDP, exports or real exchange rates (see section V.B). Although this finding strengthens our previous conclusions on the insurance benefits of indexed debt for IDA countries, it also suggests that the risk for multilateral lenders arising from prediction errors would be substantial and especially so in the case of loans indexed to the value of exports because their long run growth is hard to predict. While it appears that the risks arising from unexpected swings in exchange rates or in long-run GDP growth can be diversified, this result hinges on the assumption that GDP indexation or domestic currency lending would eventually leave the behaviour and the policies of LICs unaffected. We turn to this issue in the next section. 


\section{THE ARGUMENTS AGAINST INDEXATION}

A main argument against contingent debt is that, by linking payments to variables that are partly under the control of the debtor country, indexed loans give rise to adverse incentives and moral hazard. In the case of GDP indexation, a debtor government may behave opportunistically along three dimensions. First, GDP-indexed debt, by reducing the risk of distress and the probability of default, may favour irresponsible fiscal policies and delay fiscal adjustment. Second, it may lower the government's incentive to adopt policies that promote growth. Finally, there is the risk of 'misreporting'; a government might be tempted to manipulate GDP data in order to pay less on its debt.

In fact, opportunistic behaviour and moral hazard will always be a concern in implementing debt insurance strategies, since a trade-off between the benefits of insurance and the risk of moral hazard will naturally emerge in any such scheme. How serious is the problem is however hard to tell. While the literature is mixed, many contend that the relevance of moral hazard is exaggerated (see e.g. Griffith-Jones and Sharma, 2006; UN 2004, 2005). Indeed, it is unlikely that debtor governments would ever take deliberate actions to forestall growth because it is an important policy target for low income countries; for instance, it is crucial to attract foreign investments and other capital flows. More important, what needs to be asked is how effective conventional debt is in preventing opportunistic behaviour. The long history of debt defaults, debt restructuring and relief in low income countries does not bode well for the disciplinary effects of conventional fixed-rate debt. Furthermore, because of 'debt overhang', conventional debt does not rule out disincentive effects; a heavy debt burden may act as an implicit tax on future income and therefore reduce incentives for investment and policy reforms. By stabilizing the debt ratio against macroeconomic shocks, indexed debt can prevent debt distress and be more effective in dealing with repayment difficulties than debt relief.

The potential manipulation of GDP statistics is probably a stronger argument against the introduction of GDP-indexed loans. More generally, the low quality of national accounts, if not 'misreporting', is a serious concern in the case of low income countries despite the continuous improvement of measurement standards and the substantial effort put forth by international institutions (including the UN and the IMF) in checking for data consistency. Certainly, the reliability of national accounts would have to be improved and their verification strengthened which would imply additional costs for the implementation of an indexed lending strategy.

The delay in the release of GDP data and their revisions are other practical obstacles to the introduction of an indexation programme. However, the lag with which loan repayments reflect economic performance, due to a late release of GDP data, should be a minor problem in the case of long-term loans aimed at linking the debt to the borrower's ability to pay, since cyclical fluctuations will be spread over a long horizon ahead (see section IV). On the other hand, the fact that GDP data are subject to sizeable revisions, with new releases accruing over long periods, would require a careful design of contractual terms and conditions, for instance, the specification of a 'cut-off date' for new releases to affect amortization payments.

In light of the technical difficulties of GDP indexation, one may wonder whether inflation-indexed lending in local currencies would not provide a simpler solution to protect IDA countries from macroeconomic shocks affecting their economies. This would be a valuable innovation since the real exchange rate is quite volatile and, as shown in section VII, it tends to depreciate in bad times, impacting strongly on the borrower's capacity to pay. Indeed, domestic currency loans would reduce developing countries' exposure to exchange rate depreciations which are a major cause of vulnerability and debt crises.

Unfortunately, domestic currency debt also raises incentive issues. As the government might be tempted to monetize a debt in local currency, its payments will have to be indexed to the price level. However, while indexed debt is supposed to discipline monetary policy by increasing the cost of inflation, indexation may not work for the following reasons. First, indexation cannot dissuade the government from monetizing the debt if this does not lead to higher inflation, as it could be the case in the presence of price controls. 
Second, price indexation may not fully remove inflationary temptations since seigniorage revenues could still be collected on money demand and nominal wages. If this were the case, inflation-indexed debt would fail to protect foreign lenders from the devaluation effects of monetary expansions. In fact, purchasing power parity holds, if at all, only in the long run; while price inflation takes time to build up, the exchange rate moves fast and overshoots its long run level. As inflation translates less than one-forone into currency depreciation, it can be rational for multilateral lenders to denominate their loans in hard currencies in order to protect the real value of their investment from real exchange-rate depreciation. Summing up, while both GDP-indexed loans and inflation-indexed loans denominated in local currencies provide insurance benefits, they both raise incentive issues and moral hazard problems. Local currency denomination may lead to greater laxity in monetary policy whereas GDP indexation, and the low quality of GDP data, may favour misreporting. Evaluating the relative costs for multilateral lenders of the two debt instruments is difficult, but the benefits of contingent debt appear, in both cases, to exceed the costs.

The novelty of GDP indexation compared to inflation indexation appears instead a minor argument, especially considering that a reliable price index may not be easily available in the case of low income countries. It is also worth noting that the arguments often raised against the introduction of GDP-indexed bonds, that they are difficult to price, illiquid and a costly financial innovation, do not apply to multilateral loans because, by their nature, loans are non-marketable and thus do not require the creation of a new market for them to be traded. On the other hand, the non-marketability of loans introduces practical difficulties of a different kind that have so far not been appreciated in the literature, but are a more serious obstacle to the implementation of any programme of indexed lending.

As discussed in section IV, for GDP indexation to work, a baseline trend for GDP (or a long-run growth rate) must be specified in the debt contract, since amortization payments have to be indexed to deviations of realized GDP from its baseline trend. If this were not the case, indexed loans would be attractive only to countries with poor growth prospects. Although a baseline exchange rate does not need to be specified for lending in local currencies, such debt is not immune from the problem. This is because the real exchange rate of low income countries not only tends to appreciate in the long run through a Balassa-Samuelson effect, but the expected rate of appreciation also varies significantly across countries, as shown in section $\mathrm{V}$. This implies that, for LICs to borrow at the same expected cost as that of conventional debt, either the amount of transferred resource or their concessionality would have to be adjusted to individual countries' expected real appreciations, unless a baseline exchange rate is specified in the contract. Incidentally, it is worth noting that the correct specification of a baseline trend for GDP or the exchange rate is a minor problem in the case of marketable bonds because different specifications would be adjusted by changes in their issuing price according to the market expectations of the future values of the indexing variables.

In the case of non-marketable loans, the baseline trend has to be carefully specified in the contract and, more importantly, it must be agreed upon by the contracting parties; i.e. the borrowing country and the MDB. This clearly raises incentive issues and adverse selection problems. On the one hand, the borrower would have an obvious incentive to claim that its growth prospects are strong in order to set the highest possible baseline trend for GDP and thus reduce future debt payments. On the other hand, the MDB would want to ensure itself an expected level of reflows comparable to those on conventional loans. This conflict of interests may give rise to lengthy negotiations and an agreement could be difficult to reach. ${ }^{24}$ Things are even more complicated, if the borrower has private information about its future growth prospects. In this case, if the baseline GDP trend were set 'too low', the MDB would run the risk that only countries with weak growth potentials would self select for receiving indexed loans.

\footnotetext{
${ }^{24}$ One may wonder why a similar problem does not arise under the current Debt Sustainability Framework (DSF) arrangement, since IDA countries which receive only grants because their debt is deemed unsustainable, might want to claim a stronger growth potential in order to receive loans of a larger size than grants. However, if indexed loans were offered with a baseline GDP growth chosen out of a continuum of possible rates, the scope for disagreement would be greater.
} 
Finally, it is worth observing that negotiations about the baseline trend of GDP, or the borrower's choice between indexed and conventional loans may reveal private information by the borrower about the growth prospects of its economy and thus on the effectiveness of aid. This opens up the possibility for multilateral lenders to offer a menu of different loan contracts as a way of screening the different types of borrowers. ${ }^{25}$ While such schemes deserve further analysis, this discussion already suggests that contingent debt contracts have to be carefully designed and more research is needed to better understand their effects before a programme of indexation or domestic currency lending could ever be introduced.

\section{POLICY CONCLUSIONS}

Multilateral loans either indexed to GDP, or exports or denominated in domestic currency can reduce LICs' vulnerability to adverse shocks to GDP, the exchange rate and net exports that threaten their debt sustainability. By reducing the likelihood that debtor countries run into repayment difficulties and eventually file for debt relief, indexed debt may also benefit multilateral lenders. Of course, it can be argued that explicit debt relief provides a simpler alternative than contingent debt to cope with adverse economic events that impair the debtors' ability to pay. However, providing explicit insurance against macroeconomic shocks can be a more effective policy to deal with repayment difficulties because it avoids delays in delivering assistance, and saves on the costs of debt renegotiation and conditionality associated with explicit debt relief.

In this paper, we have evaluated the benefits and costs of indexing MDBs' loans to variables related to the LICs' ability to pay, and thus whether a reform of multilateral lending is feasible and economically justified. The analysis covers 40 IDA countries over the period between 1990 and 2010, and focus on three types of debt: foreign currency loans indexed to real GDP; foreign currency loans indexed to the dollar value of exports; and inflation-indexed loans denominated in local currency.

Portfolio risk analysis shows that there are large opportunities for risk-sharing among IDA countries, confirming previous results in the literature. Individual country risk could be easily diversified in a portfolio of loans to IDA countries, as the volatility of the MDBs' portfolio is much lower than the average volatility of individual loans for all types of indexation considered. However, the long-run growth rate of the value of exports appears more difficult to predict than the growth rates of GDP and the real exchange rate. These prediction errors result in large unexpected 10-year returns on a portfolio of export-indexed loans and thus in substantial risk for multilateral lenders.

The estimation of beta coefficients for individual country loans from a CAPM, where OECD growth is taken as the relevant market-portfolio return, suggests that the risk exposure of multilateral lenders in providing loans indexed to GDP or denominated in local currencies would be limited. Indeed, not only beta coefficients vary considerably across countries, but they are generally low in the case of GDPindexed loans and even negative, on average, for domestic currency loans. As the return on such loans is weakly correlated with OECD growth (and thus with the fiscal resources of multilateral lenders), their risk premium is no greater than one percentage point. By contrast, the risk of export-indexed loans is difficult to hedge because IDA countries' exports are strongly correlated with OECD growth. Moreover, the number of IDA countries that could be covered by a programme of export indexation is limited by the availability of export data. These findings clearly favour GDP indexation and domestic currency lending over export indexation. Loans indexed to GDP or denominated in local currencies could be introduced at current interest rates because their risk premium is low while multilateral lenders would benefit from a lower risk of debt distress.

\footnotetext{
${ }^{25}$ A similar point was made by Froot et al. (1989).
} 
We have also investigated the role of indexed loans in reducing IDA countries' vulnerability to adverse shocks to output, exports and the real exchange rate, in a model where indexed debt helps to stabilize the debt ratio and thus reduce the likelihood of a debt crisis. The optimal type of indexation depends on the conditional variances and covariances of GDP growth, real exchange-rate depreciation and net exports (at long future horizons) that can be estimated as the covariances of the forecast errors obtained from a VAR model of each IDA country over the period between 1990 and 2010.

We find strong evidence in favour of local currency loans indexed to inflation and some support to GDP indexation. Lending in the borrower's currency helps to stabilize the debt ratio against unanticipated movements in the real exchange rate that are a main cause of debt vulnerability. We also find supportive evidence for GDP-indexed loans, but while such instruments provide valuable insurance to a majority of IDA borrowers in our sample, they benefit a fewer number of countries than domestic currency loans. A main lesson from our analysis is that a 'one size fits all solution' does not exist to the problem of stabilizing the debt ratio. This result is unfortunate in that it poses an obstacle to a reform of multilateral lending that appeals to all IDA countries.

While both GDP-indexed loans and inflation-indexed loans denominated in local currency provide insurance benefits, they both raise incentive issues and heighten the risk of moral hazard. Local currency denomination may lead to greater laxity in monetary policy whereas GDP indexation may favour irresponsible fiscal policies and misreporting, also because of the low quality of GDP data. Evaluating the importance of these problems, and their relative cost for multilateral lenders, is difficult but the benefits of contingent debt appear, in both cases, to exceed the costs. If anything, the case for relying on the disciplinary effects of conventional debt is weak, as witnessed by the long history of debt defaults, debt restructuring and relief in low income countries.

Multilateral loans are immune from the pricing difficulties and liquidity problems that are major obstacles for the introduction of indexed bonds, but are sensitive to the contract design. The implementation of GDPindexed loans requires that the MDB and the borrowing country agree upon a country-specific baseline trend of GDP, since amortization payments must be indexed to deviations of realized GDP from its baseline trend for such loans to be attractive to countries with a high growth potential. This clearly raises incentive issues and adverse selection problems. In particular, we expect the borrowing country to strongly bargain over a 'high' baseline trend in order to obtain more favourable conditions. Although a baseline exchange rate does not need to be specified for lending in local currencies, the expected cost of debt service is likely to increase because in low income countries the real exchange rate tends to appreciate in the long run and at different rates in different countries. This implies that either the amount of transferred resources or their concessionality would have to be adjusted to individual countries' expected real appreciations, for them to prefer local currency debt over conventional loans. Both in the case of GDP indexation and domestic currency lending a conflict of interests is likely to arise which makes an agreement difficult to reach. This poses a serious obstacle to any programme of indexed lending. 


\section{REFERENCES}

Atta-Mensah J (2004). Commodity Linked Bonds: A Potential Means for Less-Developed Countries to Raise Foreign Capital. Bank of Canada Working Paper No. 2004-20.

Bailey N (1983). A Safety Net for Foreign Lending. Business Week, 10 January.

Barro RJ (1995). Optimal Debt Management. NBER Working Paper Series 5327.

Besley T and Powell A (1989). Commodity-Indexed debt in International Lending. Policy, Planning and Research Working Paper Series 161, World Bank. Available at: http://www-wds.worldbank.org/external/default/ WDSContentServer/IW3P/IB/1989/03/01/000009265_3960927155744/Rendered/PDF/multi_page.pdf.

Borensztein E and Mauro P (2004). The Case for GDP-Indexed Bonds. Economic Policy, 19(38): 166-216.

Caballero R (2003a). Coping with Chile's External Vulnerability: A Financial Problem. In: Loayza N and Soto R, eds., Central Banking Analysis and Economic Policies, vol. 6. Santiago, Banco Central de Chile.

Caballero R (2003b). The future of the IMF. American Economic Review, 93(2): 31-38.

Chamon M and Mauro P (2006). Pricing Growth Indexed Bonds. Journal of Banking \& Finance, 30(12): 3349-3366.

Cohen D, Jaquet P and Reisen H (2007). Loans or Grants? Review of World Economics, 143(4): 764-782.

Costa A, Chamon M and Ricci LA (2008). Is There a Novelty Premium on New Financial Instruments? The Argentine Experience with GDP-Indexed Warrants. IMF Working Paper 109.

Council of Economic Advisers (2004). Growth Indexed Bonds: A Primer. Washington, DC. Available at: http:// www.scribd.com/doc/342000/02036growthindexedbondswhitepaper.

Daniel JA (2001). Hedging Government Oil Price Risk. IMF Working Paper 185. In: Davis J, Ossowski R and Fedelino A, eds., Fiscal Policy Formulation and Implementation in Oil-Producing Countries. Washington, DC, International Monetary Fund.

Drèze JH (2000a). Economic and Social Security in the Twenty-First Century, with Attention to Europe. Scandinavian Journal of Economics, 102(3): 327-348.

Drèze JH (2000b). Globalisation and Securitisation of Risk Bearing. CORE, Université Catholique de Louvain, Belgium. In: Anckaert L, Cassimon D and Opdebeeck H, eds., Building Towers, Perspectives on Globalization: 227-235. Leuven, Peeters Publishers, 2002. Available at: http://www.core.ucl.ac.be/services/psfiles/dp01/ INA(GlobSec).pdf.

Froot KA, Scharfstein DS and Stein JC (1989). LDC Debt: Forgiveness, Indexation and Investment Incentives. The Journal of Finance, 44(5): 1335-1350.

Griffith-Jones S and Sharma K (2006). GDP-Indexed Bonds: Making It Happen. UN-DESA Working Paper 21. In: Ketkar S and Ratha D, eds., Innovative Financing for Development. World Bank Publications, 2009.

Guillaumont P, Guillaumont-Jeanneney S, Jacquet P, Chauvet L and Savoye B (2003). Attenuating through Aid the Vulnerability to Price Shocks. Article prepared for the ABCDE Europe Conference, Paris. Available at: http:// www.afd.fr/webdav/site/afd/shared/ELEMENTS_COMMUNS/article/articles2003/attenuating-vulnerabilityto-price-shocks.pdf.

Haldane A (1999). Private Sector Involvement in Financial Crisis: Analytics and Public Policy Approaches. Financial Stability Review, 7. Available at: http://www.bankofengland.co.uk/fsr/fsr07.htm.

Hausmann R and Rigobon R (2003). IDA in UF: On the Benefits of Changing the Currency Denomination of Concessional Lending to Low-Income Countries. Harvard University (mimeo). Available at: http://www.hks. harvard.edu/fs/rhausma/new/HausmannRigobonWBOS.pdf.

Helpman E (1989). The Simple Analytics of Debt-Equity Swaps. American Economic Review, 79(3): 440-451.

Kamstra MJ and Shiller RJ (2010). Trills Instead of T-Bills: It's Time to Replace Part of Government Debt with Shares in GDP. The Economists' Voice, 7(3), Article 5.

Kletzer K, Newbery D and Wright B (1992). Smoothing Primary Exporters' Price Risk: Bonds, Futures, Options and Insurance. Oxford Economic Papers, 44(4): 641-671.

Krugman P (1988). Financing vs. Forgiving a Debt Overhang. Journal of Development Economics, 29(3): 253-268.

Kruse S, Meitner M and Schröder M (2005). On the Pricing of GDP-Linked Financial Products. Applied Financial Economics, 15(16): 1125-1133. 
Lessard D (1987). Recapitalizing the Third World: Toward a New Vision of Commercial Financing for Less Developed Countries. Midland Corporate Finance Journal.

Levy Yeyati E (2007). Dollars, Debt, and International Financial Institutions: Dedollarizing Multilateral Lending. The World Bank Economic Review, 21(1): 21-47.

Lütkepohl H (2005). New Introduction to Multiple Time Series Analysis. Berlin, Springer-Verlag.

Missale A (1997). Managing the Public Debt: The Optimal Taxation Approach. Journal of Economic Surveys, 11(3): 235-265.

Obstfeld M and Peri G (1998). Regional Non-Adjustment and Fiscal Policy. In: Begg D, von Hagen J, Wyplosz C and Zimmerman K, eds., EMU: Prospects and Challenges for the Euro, Special Issue of Economic Policy, 13(26): 207-259.

Pernice S and Fagundez FL (2005). Valuation of Debt Indexed to Real Values I. The Case of Argentinean Growth Coupon: A Simple Model. CEMA Working Papers: serie Documento de trabajo: 307, Universidad del CEMA.

Ruban O, Poon SH and Vonatsos K (2008). GDP-Linked Bonds: Contract Design and Pricing. Manchester Business School Working Paper. Available at: http://papers.ssrn.com/sol3/papers.cfm?abstract_id=966436.

Schröder M, Heinemann F, Kruse S and Meitner M (2004). GDP-Linked Bonds as a Financing Tool for Developing Countries and Emerging Markets. ZEW Discussion Paper 04-64. Centre for European Economic Research, Mannheim. Available at: http://ftp.zew.de/pub/zew-docs/dp/dp0464.pdf.

Schröder M, Heinemann F, Kruse S and Meitner M (2007). Pay High in Good Times, Pay Low in Bad Times. Journal of International Development, 19: 667-683.

Shiller RJ (1993). Macro Markets: Creating Institutions for Managing Society's Largest Economic Risks. New York, Oxford University Press.

Shiller RJ (2003). The New Financial Order: Risk in the 21st Century. Princeton, NJ, Princeton University Press.

Shiller RJ (2004). Radical Financial Innovation. Cowles Foundation Discussion Paper 1461, Yale University. In: Sheshinski E, Strom RJ and Baumol WJ, eds., Entrepreneurship, Innovation and the Growth Mechanism of the Free Market Economies: 306-323. Princeton, Princeton University Press, 2006. Available at: http://cowles. econ.yale.edu/P/cd/d14b/d1461.pdf.

Shiller RJ (2005). In Favor of Growth-Linked Bonds. The Indian Express, 10 March.

Tabova A (2005). On the Feasibility and Desirability of GDP-Indexed Concessional Lending. GRADE Discussion Paper 9. Dipartimento di Scienze Economiche Università di Trento. Available at: http://www-econo.economia. unitn.it/new/pubblicazioni/papers/9_05_tabova.pdf.

United Nations (2005). Report on the Brainstorming Meeting on GDP-Indexed Bonds: Making It Happen. Washington, DC, 31 October.

United Nations (2006). Report on the brainstorming meeting on GDP-Indexed Bonds: An Idea Whose Time Has Come. Washington, DC, 21 April. 


\begin{tabular}{|c|c|c|c|}
\hline No. & Date & Author(s) & Title \\
\hline 208 & October 2012 & $\begin{array}{l}\text { David Bicchetti and } \\
\text { Nicolas Maystre }\end{array}$ & $\begin{array}{l}\text { The synchronized and long-lasting structural change on } \\
\text { commodity markets: Evidence from high frequency data }\end{array}$ \\
\hline 207 & July 2012 & $\begin{array}{l}\text { Amelia U. Santos- } \\
\text { Paulino }\end{array}$ & $\begin{array}{l}\text { Trade, income distribution and poverty in developing } \\
\text { countries: A survey }\end{array}$ \\
\hline 206 & December 2011 & $\begin{array}{l}\text { André Nassif, } \\
\text { Carmem Feijó } \\
\text { and Eliane Araújo }\end{array}$ & $\begin{array}{l}\text { The long-term "optimal" real exchange rate and } \\
\text { the currency overvaluation trend in open emerging } \\
\text { economies: The case of Brazil }\end{array}$ \\
\hline 205 & December 2011 & Ulrich Hoffmann & $\begin{array}{l}\text { Some reflections on climate change, green growth } \\
\text { illusions and development space }\end{array}$ \\
\hline 204 & October 2011 & Peter Bofinger & The scope for foreign exchange market interventions \\
\hline 203 & September 2011 & $\begin{array}{l}\text { Javier Lindenboim, } \\
\text { Damián Kennedy and } \\
\text { Juan M. Graña }\end{array}$ & $\begin{array}{l}\text { Share of labour compensation and aggregate demand } \\
\text { discussions towards a growth strategy }\end{array}$ \\
\hline 202 & June 2011 & Pilar Fajarnes & $\begin{array}{l}\text { An overview of major sources of data and analyses } \\
\text { relating to physical fundamentals in international } \\
\text { commodity markets }\end{array}$ \\
\hline 201 & February 2011 & Ulrich Hoffmann & $\begin{array}{l}\text { Assuring food security in developing countries under the } \\
\text { challenges of climate change: Key trade and development } \\
\text { issues of a fundamental transformation of agriculture }\end{array}$ \\
\hline 200 & September 2010 & Jörg Mayer & Global rebalancing: Effects on trade flows and employment \\
\hline 199 & June 2010 & $\begin{array}{l}\text { Ugo Panizza, } \\
\text { Federico Sturzenegger } \\
\text { and Jeromin Zettelmeyer }\end{array}$ & International government debt \\
\hline 198 & April 2010 & $\begin{array}{l}\text { Lee C. Buchheit and } \\
\text { G. Mitu Gulati }\end{array}$ & Responsible sovereign lending and borrowing \\
\hline 197 & March 2010 & Christopher L. Gilbert & $\begin{array}{l}\text { Speculative influences on commodity futures prices } \\
2006-2008\end{array}$ \\
\hline 196 & November 2009 & Michael Herrmann & $\begin{array}{l}\text { Food security and agricultural development in times of } \\
\text { high commodity prices }\end{array}$ \\
\hline 195 & October 2009 & Jörg Mayer & $\begin{array}{l}\text { The growing interdependence between financial and } \\
\text { commodity markets }\end{array}$ \\
\hline 194 & June 2009 & Andrew Cornford & $\begin{array}{l}\text { Statistics for international trade in banking services: } \\
\text { Requirements, availability and prospects }\end{array}$ \\
\hline 193 & January 2009 & Sebastian Dullien & $\begin{array}{l}\text { Central banking, financial institutions and credit creation } \\
\text { in developing countries }\end{array}$ \\
\hline 192 & November 2008 & Enrique Cosio-Pascal & $\begin{array}{l}\text { The emerging of a multilateral forum for debt } \\
\text { restructuring: The Paris Club }\end{array}$ \\
\hline 191 & October 2008 & Jörg Mayer & Policy space: What, for what, and where? \\
\hline 190 & October 2008 & Martin Knoll & $\begin{array}{l}\text { Budget support: A reformed approach or old wine in new } \\
\text { skins? }\end{array}$ \\
\hline 189 & September 2008 & Martina Metzger & Regional cooperation and integration in sub-Saharan Africa \\
\hline 188 & March 2008 & Ugo Panizza & $\begin{array}{l}\text { Domestic and external public debt in developing } \\
\text { countries }\end{array}$ \\
\hline 187 & February 2008 & Michael Geiger & $\begin{array}{l}\text { Instruments of monetary policy in China and their } \\
\text { effectiveness: 1994-2006 }\end{array}$ \\
\hline
\end{tabular}




\begin{tabular}{|c|c|c|c|}
\hline No. & Date & Author(s) & Title \\
\hline 186 & January 2008 & Marwan Elkhoury & $\begin{array}{l}\text { Credit rating agencies and their potential impact on } \\
\text { developing countries }\end{array}$ \\
\hline 185 & July 2007 & Robert Howse & The concept of odious debt in public international law \\
\hline 184 & May 2007 & André Nassif & $\begin{array}{l}\text { National innovation system and macroeconomic policies: } \\
\text { Brazil and India in comparative perspective }\end{array}$ \\
\hline 183 & April 2007 & Irfan ul Haque & Rethinking industrial policy \\
\hline 182 & October 2006 & Robert Rowthorn & $\begin{array}{l}\text { The renaissance of China and India: implications for the } \\
\text { advanced economies }\end{array}$ \\
\hline 181 & October 2005 & Michael Sakbani & $\begin{array}{l}\text { A re-examination of the architecture of the international } \\
\text { economic system in a global setting: Issues and proposals }\end{array}$ \\
\hline 180 & October 2005 & $\begin{array}{l}\text { Jörg Mayer and } \\
\text { Pilar Fajarnes }\end{array}$ & Tripling Africa's Primary Exports: What? How? Where? \\
\hline 179 & April 2005 & S.M. Shafaeddin & $\begin{array}{l}\text { Trade liberalization and economic reform in developing } \\
\text { countries: structural change or de-industrialization? }\end{array}$ \\
\hline 178 & April 2005 & Andrew Cornford & Basel II: The revised framework of June 2004 \\
\hline 177 & April 2005 & Benu Schneider & $\begin{array}{l}\text { Do global standards and codes prevent financial crises? } \\
\text { Some proposals on modifying the standards-based approach }\end{array}$ \\
\hline 176 & December 2004 & Jörg Mayer & $\begin{array}{l}\text { Not totally naked: textiles and clothing trade in a quota } \\
\text { free environment }\end{array}$ \\
\hline 175 & August 2004 & S.M. Shafaeddin & $\begin{array}{l}\text { Who is the master? Who is the servant? Market or } \\
\text { Government? }\end{array}$ \\
\hline 174 & August 2004 & Jörg Mayer & $\begin{array}{l}\text { Industrialization in developing countries: some evidence } \\
\text { from a new economic geography perspective }\end{array}$ \\
\hline 173 & June 2004 & Irfan ul Haque & Globalization, neoliberalism and labour \\
\hline 172 & June 2004 & Andrew J. Cornford & $\begin{array}{l}\text { The WTO negotiations on financial services: current } \\
\text { issues and future directions }\end{array}$ \\
\hline 171 & May 2004 & Andrew J. Cornford & Variable geometry for the WTO: concepts and precedents \\
\hline 170 & May 2004 & $\begin{array}{l}\text { Robert Rowthorn and } \\
\text { Ken Coutts }\end{array}$ & $\begin{array}{l}\text { De-industrialization and the balance of payments in } \\
\text { advanced economies }\end{array}$ \\
\hline 169 & April 2004 & Shigehisa Kasahara & $\begin{array}{l}\text { The flying geese paradigm: a critical study of its } \\
\text { application to East Asian regional development }\end{array}$ \\
\hline 168 & February 2004 & Alberto Gabriele & $\begin{array}{l}\text { Policy alternatives in reforming power utilities in } \\
\text { developing countries: a critical survey }\end{array}$ \\
\hline 167 & January 2004 & $\begin{array}{l}\text { Richard Kozul-Wright } \\
\text { and Paul Rayment }\end{array}$ & Globalization reloaded: an UNCTAD Perspective \\
\hline 166 & February 2003 & Jörg Mayer & The fallacy of composition: a review of the literature \\
\hline 165 & November 2002 & Yuefen Li & China's accession to WTO: exaggerated fears? \\
\hline 164 & November 2002 & $\begin{array}{l}\text { Lucas Assuncao and } \\
\text { ZhongXiang Zhang }\end{array}$ & Domestic climate change policies and the WTO \\
\hline 163 & November 2002 & A.S. Bhalla and S. Qiu & $\begin{array}{l}\text { China's WTO accession. Its impact on Chinese } \\
\text { employment }\end{array}$ \\
\hline 162 & July 2002 & $\begin{array}{l}\text { Peter Nolan and } \\
\text { Jin Zhang }\end{array}$ & The challenge of globalization for large Chinese firms \\
\hline 161 & June 2002 & $\begin{array}{l}\text { Zheng Zhihai and } \\
\text { Zhao Yumin }\end{array}$ & China's terms of trade in manufactures, 1993-2000 \\
\hline 160 & June 2002 & S.M. Shafaeddin & $\begin{array}{l}\text { The impact of China's accession to WTO on exports of } \\
\text { developing countries }\end{array}$ \\
\hline
\end{tabular}




\begin{tabular}{|c|c|c|c|}
\hline No. & Date & Author(s) & Title \\
\hline 159 & May 2002 & $\begin{array}{l}\text { Jörg Mayer, } \\
\text { Arunas Butkevicius } \\
\text { and Ali Kadri }\end{array}$ & Dynamic products in world exports \\
\hline 158 & April 2002 & $\begin{array}{l}\text { Yılmaz Akyüz and } \\
\text { Korkut Boratav }\end{array}$ & The making of the Turkish financial crisis \\
\hline 157 & September 2001 & Heiner Flassbeck & The exchange rate: Economic policy tool or market price? \\
\hline 156 & August 2001 & Andrew J. Cornford & $\begin{array}{l}\text { The Basel Committee's proposals for revised capital } \\
\text { standards: Mark } 2 \text { and the state of play }\end{array}$ \\
\hline 155 & August 2001 & Alberto Gabriele & $\begin{array}{l}\text { Science and technology policies, industrial reform and } \\
\text { technical progress in China: Can socialist property rights } \\
\text { be compatible with technological catching up? }\end{array}$ \\
\hline 154 & June 2001 & Jörg Mayer & $\begin{array}{l}\text { Technology diffusion, human capital and economic } \\
\text { growth in developing countries }\end{array}$ \\
\hline 153 & December 2000 & Mehdi Shafaeddin & $\begin{array}{l}\text { Free trade or fair trade? Fallacies surrounding the theories } \\
\text { of trade liberalization and protection and contradictions in } \\
\text { international trade rules }\end{array}$ \\
\hline 152 & December 2000 & Dilip K. Das & Asian crisis: Distilling critical lessons \\
\hline 151 & October 2000 & Bernard Shull & $\begin{array}{l}\text { Financial modernization legislation in the United States - } \\
\text { Background and implications }\end{array}$ \\
\hline 150 & August 2000 & Jörg Mayer & $\begin{array}{l}\text { Globalization, technology transfer and skill accumulation } \\
\text { in low-income countries }\end{array}$ \\
\hline 149 & July 2000 & Mehdi Shafaeddin & $\begin{array}{l}\text { What did Frederick List actually say? Some clarifications } \\
\text { on the infant industry argument }\end{array}$ \\
\hline 148 & April 2000 & Y1lmaz Akyüz & $\begin{array}{l}\text { The debate on the international financial architecture: } \\
\text { Reforming the reformers }\end{array}$ \\
\hline 147 & April 2000 & Martin Khor & Globalization and the South: Some critical issues \\
\hline 146 & February 2000 & $\begin{array}{l}\text { Manuel R. Agosin and } \\
\text { Ricardo Mayer }\end{array}$ & $\begin{array}{l}\text { Foreign investment in developing countries: Does it } \\
\text { crowd in domestic investment? }\end{array}$ \\
\hline 145 & January 2000 & $\begin{array}{l}\text { B. Andersen, } \\
\text { Z. Kozul-Wright and } \\
\text { R. Kozul-Wright }\end{array}$ & $\begin{array}{l}\text { Copyrights, competition and development: The case of } \\
\text { the music industry }\end{array}$ \\
\hline
\end{tabular}

Copies of UNCTAD Discussion Papers may be obtained from the Publications Assistant, Macroeconomic and Development Policies Branch (MDPB), Division on Globalization and Development Strategies (DGDS), United Nations Conference on Trade and Development (UNCTAD), Palais des Nations, CH-1211 Geneva 10, Switzerland (fax no: +41 (0)22 917 0274).

UNCTAD Discussion Papers are accessible on the website at http://www.unctad.org. 